\title{
19. PALEOENVIRONMENTAL EVOLUTION OF THE WALVIS RIDGE DEDUCED FROM INORGANIC GEOCHEMICAL AND CLAY MINERALOGICAL DATA, DEEP SEA DRILLING PROJECT LEG 74, SOUTHEAST ATLANTIC ${ }^{1}$
}

\author{
Henri Maillot, Sédimentologie et Géochimie, E.R.A. C.N.R.S. 764, Université de Lille I, \\ 59655 Villeneuve d'Ascq Cedex, France \\ and \\ Christian Robert, Géologie Marine, L.A. C.N.R.S. 41, Facultè des Sciences de Luminy, Case 901, \\ 13288 Marseille Cedex 9, France
}

\begin{abstract}
Clay mineralogical and inorganic geochemical data from the Campanian to the Pleistocene provide information bearing on the evolution of both continental and marine paleoenvironments in the Walvis Ridge area. (1) Alteration processes of basalts occurred under subaerial conditions during the Campanian and Maestrichtian and were virtually absent in deeper marine environments. (2) Strong tectonic effects were present during the Campanian and persisted until the early Eocene. (3) Subsidence of this part of the Walvis Ridge became important during the late Maestrichtian and continued into the Paleocene and Eocene. (4) The influence of global climatic cooling was evident from the late Eocene on. (5) Modification of oceanic circulation and the increasing influence of surface and deep water masses on the sedimentation characterized the Cenozoic.
\end{abstract}

\section{INTRODUCTION}

During Leg 74 of the Deep Sea Drilling Project, five sites were drilled on the Walvis Ridge (Fig. 1). The sediments recovered range from Pleistocene to Campanian. Site characteristics are summarized in the following:

\begin{tabular}{|c|c|c|c|c|c|c|}
\hline \multirow[b]{2}{*}{ Site } & \multirow{2}{*}{$\begin{array}{l}\text { Latitude } \\
\text { Longitude }\end{array}$} & \multirow{2}{*}{$\begin{array}{l}\text { Water } \\
\text { Depth } \\
\text { (m) }\end{array}$} & \multirow{2}{*}{$\begin{array}{l}\text { Penetr. } \\
\text { (m) }\end{array}$} & \multicolumn{2}{|c|}{$\begin{array}{l}\text { Number of } \\
\text { Samples }\end{array}$} & \multirow{2}{*}{$\begin{array}{c}\text { Oldest } \\
\text { Sediment } \\
\text { Recovered }\end{array}$} \\
\hline & & & & Min. & Chem. & \\
\hline 526 & $\begin{array}{l}30^{\circ} 07.36^{\prime} \mathrm{S} \\
03^{\circ} 08.28^{\prime} \mathrm{E}\end{array}$ & 1064 & 619 & 63 & - & Paleocene \\
\hline 525 & $\begin{array}{l}29^{\circ} 04.24^{\prime} \mathrm{S} \\
02^{\circ} 52.12^{\prime} \mathrm{E}\end{array}$ & 2477 & 678 & 99 & 47 & $\begin{array}{l}\text { Campanian } \\
\text { on basement }\end{array}$ \\
\hline 529 & $\begin{array}{l}28^{\circ} 55.83^{\prime} \mathrm{S} \\
02^{\circ} 46.08^{\prime} \mathrm{E}\end{array}$ & 3035 & 417 & 45 & 13 & Maestrichtian \\
\hline 528 & $\begin{array}{l}28^{\circ} 31.49^{\prime} \mathrm{S} \\
02^{\circ} 19.44^{\prime} \mathrm{E}\end{array}$ & 3810 & 555 & 81 & 45 & $\begin{array}{l}\text { Maestrichtian } \\
\text { on basement }\end{array}$ \\
\hline 527 & $\begin{array}{l}28^{\circ} 02.49^{\prime} \mathrm{S} \\
01^{\circ} 45.80^{\prime} \mathrm{E}\end{array}$ & 4428 & 384 & 46 & 29 & $\begin{array}{l}\text { Maestrichtian } \\
\text { on basement }\end{array}$ \\
\hline
\end{tabular}

The purpose of this study is to assist in the reconstruction of paleoenvironmental conditions in the region by looking at the clay mineralogy and inorganic geochemistry. Similar approaches have been used in the past to determine the paleoenvironmental evolution of the South Atlantic: (1) Cretaceous formation of the South Atlantic basins (Robert et al., 1979; Maillot, 1980; Maillot et Robert, 1980) and paleoenvironmental conditions during deposition of black shales (Chamley and Robert, in press); (2) Cretaceous/Tertiary boundary events on the Atlantic margins (Chamley and Robert, 1979), on the Rio Grande Rise (Robert, 1981), and on the

${ }^{1}$ Moore, T. C., Jr., Rabinowitz, P. D., et al., Init. Repts. DSDP, 74: Washington (U.S. Govt. Printing Office).

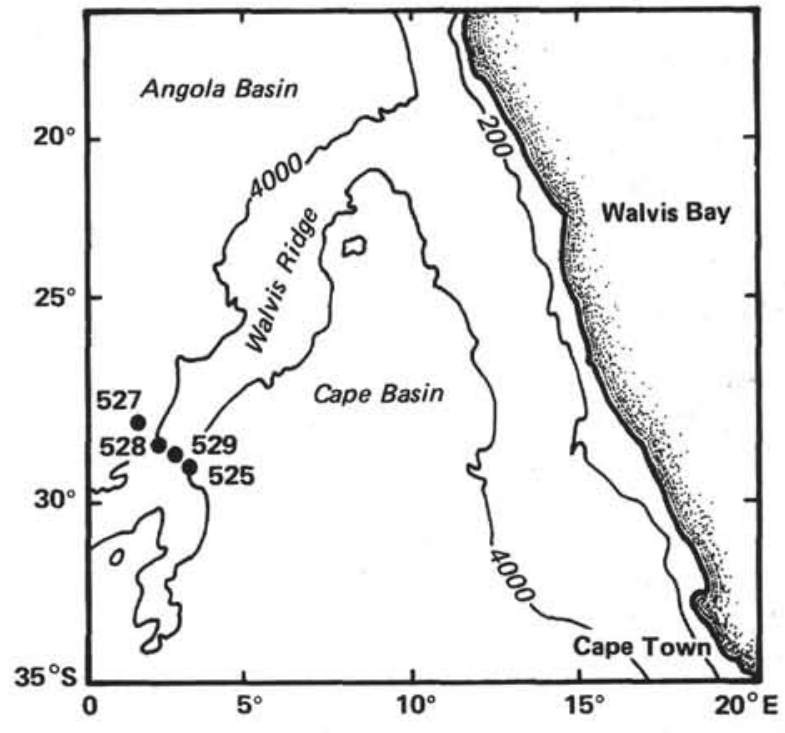

Figure 1. Site locations, Leg 74.

Walvis Ridge (Chamley et al., this volume); (3) Cenozoic changes in climates and currents in the South Atlantic (Maillot and Robert, 1980; Robert, 1980); and (4) paleoenvironmental changes of the Falkland plateau area from Jurassic to Pleistocene (Robert and Maillot, in press).

\section{METHODOLOGY}

\section{Clay Mineralogy}

The study involved the analysis of 334 samples. In each, the sediment fraction $<63 \mu \mathrm{m}$ was decalcified in $0.2 \mathrm{~N}$ hydrochloric acid. The excess acid was removed by repeated centrifuging followed by homogenization. The $<2-\mu \mathrm{m}$ fraction was separated by decantation (settling time based on Stokes' law) and oriented aggregates made on glass slides. Three X-ray diffractograms were made using (1) an untreated sample, (2) a glycolated sample, and (3) a sample heated for $2 \mathrm{hr}$. at $490^{\circ} \mathrm{C}$. A 
C.G.R. Thêta 60 diffractometer (copper $\mathrm{K} \alpha$ radiation focused by a quartz curved crystal monochromator) was used at scan speeds of $1^{\circ} 2$ $\theta / \mathrm{min}$. with all instrument settings kept constant. A receiving slit of 1.25 $\mathrm{mm}$ ensured precise resolution of poorly crystallized minerals.

The minerals recognized include chlorite, illite, irregular mixed layers (chlorite-smectite and illite-smectite), kaolinite, smectite, and attapulgite (palygorskite and sepiolite). Associated minerals were quartz, feldspar, goethite, cristobalite, and clinoptilolite in variable abundance.

Semiquantitative evaluations were based on the peak heights and areas. The height of the 001 illite peak (glycolated sample) was taken as a reference. Compared to this value, smectite, attapulgite, and irregular mixed layers were corrected by multiplying their peak height by a factor of 1.5 to 2.5 , depending on their crystallinity, whereas well-crystallized kaolinite was corrected using a factor of 0.5 . Final data are given in percentages, the relative error being $\pm 5 \%$.

\section{Geochemistry}

The samples were dried at $105^{\circ} \mathrm{C}$, then ground and homogenized. Sub-samples weighing $0.2 \mathrm{~g}$ were subjected to alkaline fusion, then dissolved in $\mathrm{HCl}$ and diluted to $100 \mathrm{ml}$. The treatment allowed gravimetric determination of $\mathrm{SiO}_{2}$ and spectrophotometric determination of $\mathrm{CaO}$, $\mathrm{MgO}, \mathrm{Al}_{2} \mathrm{O}_{3}$, and $\mathrm{Fe}_{2} \mathrm{O}_{3}$ (by atomic absorption). Another $2 \mathrm{~g}$ of each sample were submitted to fluoroperchloric treatment, then dissolved in $\mathrm{HCl}$ and diluted to $100 \mathrm{ml}$. The dilution was used for the colorimetric analysis of $\mathrm{TiO}_{2}$ and the spectrophotometric analysis of $\mathrm{Na}_{2} \mathrm{O}$ and $\mathrm{K}_{2} \mathrm{O}$ (by emission) and of $\mathrm{Mn}, \mathrm{Zn}, \mathrm{Li}, \mathrm{Ni}, \mathrm{Cr}, \mathrm{Sr}, \mathrm{Co}, \mathrm{Cu}, \mathrm{Pb}, \mathrm{V}$, and $\mathrm{Cd}$ (by atomic absorption). The emission and atomic absorption apparatus was a Type 503 Perkin-Elmer spectrophotometer using (1) base solution for major elements and (2) complex synthetic solution for trace elements to which $5 \%$ lanthane in a hydrochloric solution was added.

\section{GENERAL RESULTS}

\section{Clay Mineralogy}

In general, clay mineral assemblages from Leg 74 sites show the absence of diagenesis with the depth of burial. Although the influence of burial depth on the diagenesis of clay minerals has been observed by Dunoyer (1969) for deeper boreholes, there is neither progressive transition from smectite to mixed layers and illite nor reduction in illite crystallinity with increased depth at the sites under discussion.

Volcanogenic smectite is abundant at Site 525, in a shallow water environment, and results from subaerial alteration of basalts. Deeper Sites 527 and 528 probably contain some volcanogenic smectite in the sediments intercalated in basalts. However, diversified clay assemblages appear very soon after occurrences of basalt, indicating the dominant detrital character of clay particles (Chamley et al., this volume).

As there is no evidence for authigenesis of clay minerals in sediments in this part of the South Atlantic, they are considered to be essentially of detrital origin and to have formed in soils and by continental weathering as is the case in the North Atlantic (Chamley, 1979) and in other parts of the South Atlantic (Robert, 1981; Robert and Maillot, in press).

In the Atlantic, Cretaceous sediments contain kaolinite and large amounts of well-crystallized smectite, similar to the pedogenic smectite presently originating from African regions (Paquet, 1969). These minerals point to the existence of a globally hot continental climate, in agreement with the data compiled by Frakes (1979). The characteristics of clay mineral assemblages produced during long periods of constant warm climatic conditions (Millot, 1964; Chamley, 1979; Robert et al.,
1979) include the following: (1) Chlorite, illite, and mixed layers result principally from the direct erosion of rocks and from moderate continental weathering. (2) Kaolinite is derived from soils developed in sloping and well-drained upstream areas. (3) Except in some Upper Cretaceous and Paleogene levels where volcanogenic smectite is abundant, this mineral comes mainly from deep soils in downstream areas of continental drainage basins where relief is low and drainage poor. (4) Palygorskite (attapulgite) is derived mainly from sediments of confined coastal basins.

In the sediments from Leg 74, direct erosion of rocks, moderate continental weathering, and a sloping continental morphology characterize the vicinity of the sites in the Late Cretaceous. This influence is less evident at Site 529, where Cretaceous sediments are poorly represented, and at Site 525, where abundant volcanogenic smectite can dilute the detrital supply (Chamley et al., this volume).

In Cenozoic sediments, especially since the late Eocene, the abundance of chlorite, illite, and mixed layers increases progressively, following the general climate cooling (Chamley, 1979) and the latitudinal zonation of climates and soils (Goldberg and Griffin, 1964; Pedro, 1968). The distribution of clay minerals in the ocean depends on several factors, the most important being the influence of oceanic water masses and circulation (Robert, 1980). In the Plio-Pleistocene sediments of the South Atlantic, intermediate water masses are enriched in illite and mixed-layers originating from temperate areas; the North Atlantic Deep Water is marked by kaolinite from equatorial regions, and Antarctic Bottom Water contains a significant concentration of smectite (Chamley, 1975). The general climatic trend is evident in fluctuations in the abundance of the minerals in all Cenozoic sediments from Leg 74. Moreover, chlorite, illite, and mixed layers seem more important at shallower sites, suggesting an influence of the different water masses on sedimentation.

\section{Geochemistry}

In oceanic sediments, $\mathrm{Fe}$ and $\mathrm{Mn}$ accumulations originate from detrital (fine or coarse fraction), hydrogenous and biogenic, volcanogenic sources or from diagenetic processes (Elderfield, 1977). Despite the variety of origin, it seems that the relative abundances of $\mathrm{Fe}$ and $\mathrm{Mn}$ are significant and may be used for paleoenvironmental studies (Turekian, 1965; Boström et al., 1972; Maillot, 1980; Maillot and Robert, 1980). For Krishnaswani (1976), Fe-Mn values higher than those in typical detrital shale indicate an authigenic influence in the sediment formation. The index

$$
\mathrm{Mn}^{*}=\log \frac{\text { Mn sample }}{\text { Mn shale }} / \frac{\mathrm{Fe} \text { sample }}{\mathrm{Fe} \text { shale }}
$$

was used, the values of $\mathrm{Mn}$ shale and Fe shale being given by Bostrom et al. (1976). The variations in this index are considered to be due to the influence of oceanic basalts and oxidizing currents. 
$\mathrm{Al}$ is principally related to the detrital minerals. An index proposed by Boström $(1969,1970)$ permits us to identify detrital particles $\mathrm{D}^{*}=\mathrm{Al} / \mathrm{Al}+\mathrm{Fe}+\mathrm{Mn}$ and is associated with $\mathrm{Si}^{*}=\mathrm{SiO}_{2} / \mathrm{Al}_{2} \mathrm{O}_{3}$ (siltstones, sandstones). $\mathrm{D}^{*}$ is close to 0.63 in typical terrigenous shales. A decrease in $\mathrm{D}^{*}$ points to a less significant continental influence on sedimentation. Very high values of $\mathrm{D}^{*}$ sometimes correspond to abundant kaolinite particles. $\mathrm{Si}^{*}$ expresses the excess $\mathrm{Si}-$ i.e., $\mathrm{Si}$ not associated with Al. It can derive from volcanogenic (ash) or be biogenic (diatoms, radiolarians) or detrital (quartz) in origin.

The ratios $\mathrm{Mg}^{*}=\mathrm{MgO} / \mathrm{Al}_{2} \mathrm{O}_{3}$ and $\mathrm{Fe}^{*}=\mathrm{Fe}_{2} \mathrm{O}_{3} /$ $\mathrm{Al}_{2} \mathrm{O}_{3}$ permit the interpretation of variations in $\mathrm{MgO}$ and $\mathrm{Fe}_{2} \mathrm{O}_{3}$ with respect to clay mineral abundances and species (illite, smectites: nonferrous or $\mathrm{Al}-\mathrm{Fe}$ clays, palygorskites, etc.).

The index $\mathrm{Sr}^{*}=10^{3}(\mathrm{Sr} / \mathrm{CaO})$ is generally related to processes of carbonate dissolution (Maillot and Robert, 1980). When the variations related to burial diagenesis or to the primary composition of the carbonates are mathematically determined, $\mathrm{Sr}^{*}$ confirms the processes of carbonate dissolution as inferred by other methods (Maxwell, Von Herzen, et al., 1970; van Andel et al., 1977; Melguen, 1978; Melguen, LePichon, et al., 1978). Three sorts of dissolution appear. (1) Very high $\mathrm{Sr}^{*}$ : This type of dissolution is present in sediments rich in organic matter and depends on the intensity of the reduced sedimentary environment. (2) High $\mathrm{Sr}^{*}$ : In open marine and oxidizing environments, this type of dissolution appears in the vicinity of the carbonate compensa- tion depth (CCD). High Sr* values result from the low solubility of $\mathrm{SrCO}_{3}$ compared with $\mathrm{CaCO}_{3}$ (Nekrassov, 1966) or from the partial adsorption of $\mathrm{Sr}$ by clay minerals (Baush, 1968). (3) Low Sr*: This type of dissolution occurs when the sediment has been deposited above the CCD.

\section{WALVIS RIDGE}

Site 526

\section{Lithology}

Sediments vary from calcareous oozes, often containing abundant foraminifers, to shallow-water calcareous sands (Site 526 chapter). The sediments cored at Site 526 range from late Paleocene to late Pleistocene. (See Fig. 2 for lithologic symbols.)

The base of the sedimentary section (see Fig. 3) consists of upper Paleocene and upper Eocene fossiliferous calcareous sands and sandstones; the noncalcareous fraction (20-40\%) includes volcanic glass, palagonite, quartz, feldspar, and glauconite. This is overlain by rubbly, highly fossiliferous limestone facies of late Eocene age. Through the lower Oligocene, the sediment consists of a foraminifer-nannofossil ooze with minor, nannofossil ooze and foraminifer-nannofossil chalk. The upper Oligocene to lower Miocene sediments consist of a nannofossil ooze. Middle Miocene, Pliocene, and Pleistocene sediments include' sand-sized foraminifer ooze, nannofossil-foraminifer ooze, foraminifer-

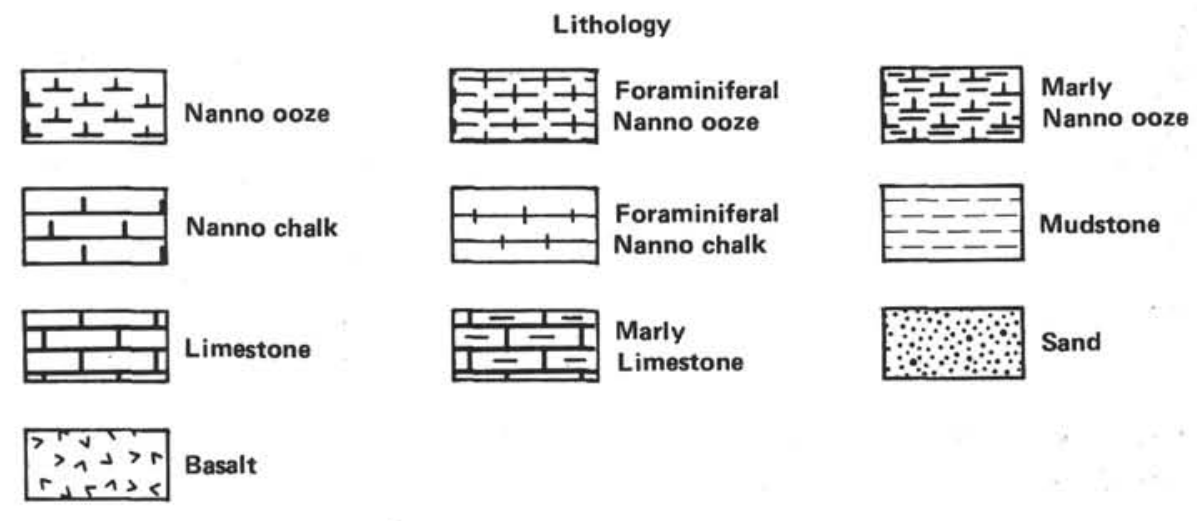

Clay Minerals

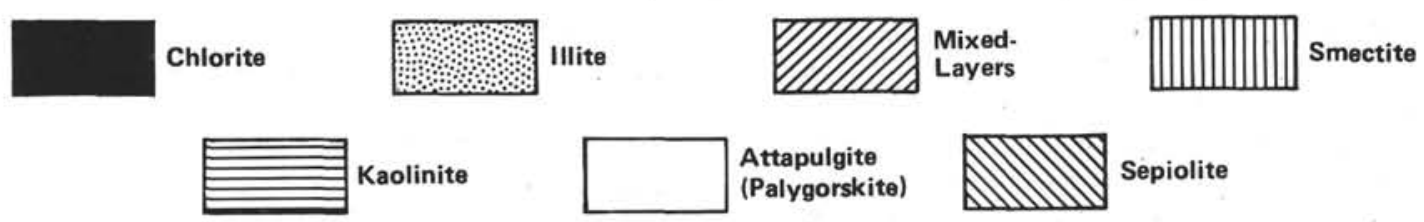

Accessory Minerals
- Rare
Common
O Abundant
Very abundant

Figure 2. Symbols used in graphic lithology columns (sediment), Figs. 3-9. 


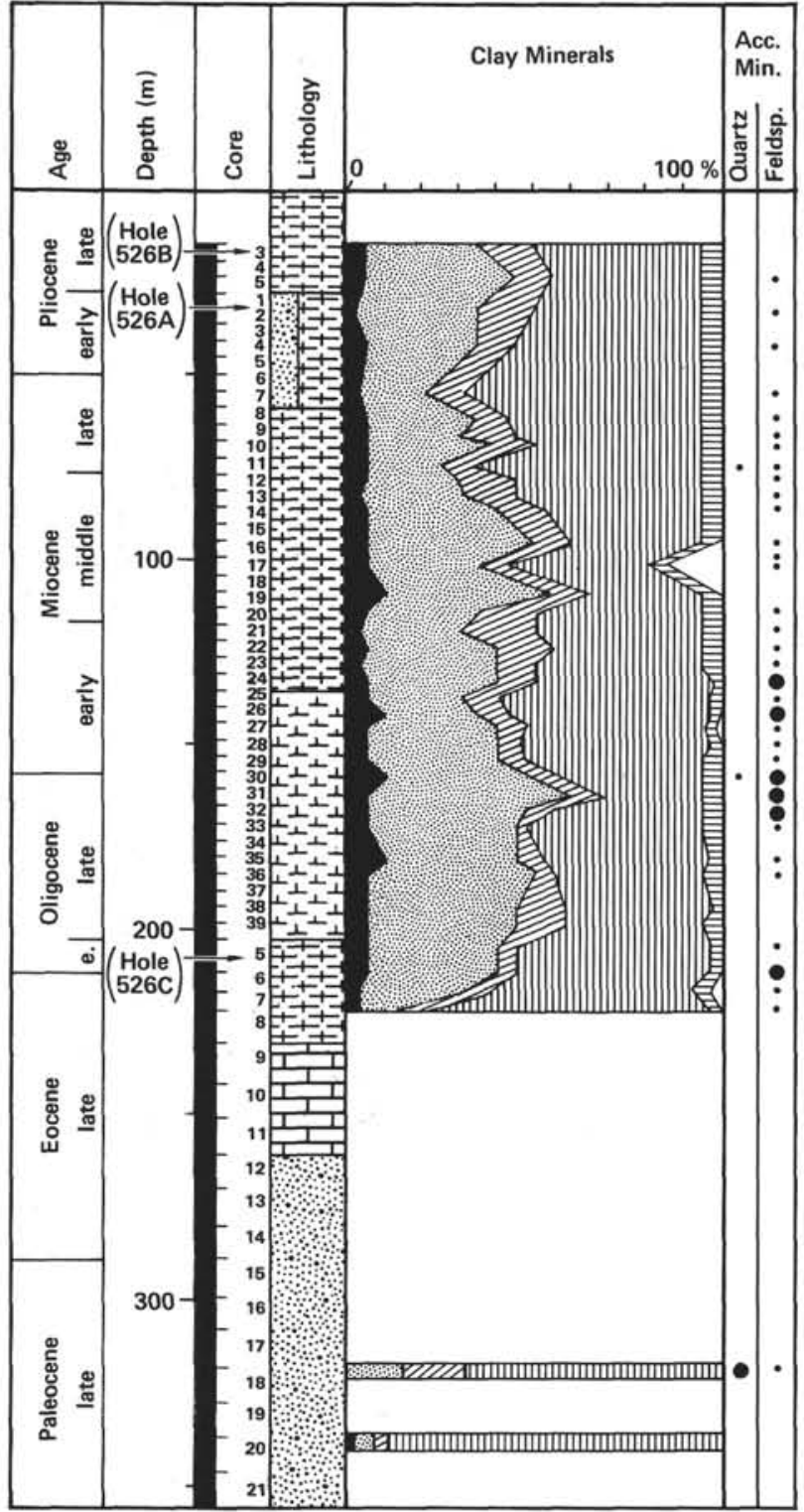

Figure 3. Site 526 results.

nannofossil ooze, and nannofossil ooze. A break in the accumulation of pelagic sediments is found in the lowermost Oligocene.

\section{Clay Mineralogy}

In upper Paleocene and upper Eocene sediments (Hole 526C, Cores 8, 18, and 20), smectite is the most abundant mineral $(70-90 \%)$. It is accompanied by chlorite $(5 \%)$, illite (5 to $15 \%)$, mixed-layers $(5-15 \%)$, and kaolinite $(0-5 \%)$. Quartz and feldspar are also present.

From upper Eocene to upper Pliocene (Hole 526C, Cores 5-7; Hole 526A, Cores 1-39; Hole 526B, Cores $3-5)$ illite increases significantly $(15-50 \%)$. Chlorite $(5-10 \%)$, mixed-layers $(5-20 \%)$, and kaolinite (trace amounts to $5 \%$ ) also increase. Palygorskite is present episodically until middle Miocene (trace amounts to $15 \%$; Plate 1). Quartz and feldspar are also present. These results, which indicate the importance of illite principally from the late Eocene on, point to the importance of climatic control on clay sedimentation.

\section{Site $\mathbf{5 2 5}$}

\section{Lithology (Fig. 4)}

The complete sedimentary section (Site 525, chapter) consists of Campanian to Pleistocene sediments rich to moderately rich in biogenic calcareous components (Site 525 chapter). The sediments interbedded between Campanian basalts include fine-grained, marly limestones, noncalcareous mudstones, cherts, porcellanite, and volcaniclastics. The upper Campanian to Maestrichtian interval is represented by cyclic sedimentation of alternating beds of chalk, calcareous siltstone and sandstone, and marly limestones. The upper part of the sedimentary column (Paleocene-Quaternary) consists of nannofossil and foraminifer-nannofossil ooze and chalk.

\section{Clay Mineralogy (Fig. 4)}

In Campanian to upper Paleocene sediments (Hole $525 \mathrm{~A}$, Cores 52-35), smectite dominates the clay assemblages $(40-100 \%)$. This mineral is accompanied by chlorite $(0-5 \%)$, illite $(0-25 \%)$, mixed-layers $(0-10 \%)$ kaolinite $(0$ to $10 \%)$, palygorskite $(0-10 \%)$, and sepiolite (0-trace amounts). Quartz, feldspar, cristobalite, and clinoptilolite are also present. This clay mineral association, common during the Cretaceous/Tertiary transition, reflects an influence of tectonics on sedimentation (Chamley and Robert, 1979). The weakness of this influence at Site 525 is probably due to the dilution of the detrital supply by smectite originating from subaerial alteration of basalts (Chamley et al., this volume).

From upper Paleocene to middle Eocene (Hole 525A, Cores 31-20) the abundance of smectite decreases slightly $(50-80 \%)$, and palygorskite $(0-20 \%)$, illite (5 to $25 \%$ ), and mixed-layer clays (10-15\%) increase. Chlorite, kaolinite, and sepiolite disappear. Quartz, feldspar, and clinoptilolite are also present. Detrital particles originating from both direct erosion of moderately weathered rocks and confined coastal basins are present contemporaneously in the sediment, mixed with pedogenic smectite from flat coastal lowlands.

From the upper Oligocene up (Hole 525A, Cores 19 and 17-9; Hole 525B, Core 50), the slight decrease in the abundance of smectite $(40-75 \%)$ is balanced by the presence of chlorite (trace amounts-5\%), illite (10-20\%), mixed-layers (5-20\%), and kaolinite (trace amounts$5 \%$ ). Quartz and feldspar are also present; clinoptilolite occurs in upper Oligocene and lower Miocene sediments only. This relative importance of primary minerals and mixed-layer clays is related to progressive climatic cooling (Chamley, 1979).

\section{Geochemistry (Fig. 4 and Table 1)}

In Campanian to lower Maestrichtian sediments, average values of $\mathrm{D}^{*}=0.55$ and $\mathrm{Mn}^{*}=0.36$ suggest the presence of an open marine environment or subaerial alteration of volcanic component (see Chamley et al., this volume). Relatively high values of $\mathrm{Sr}^{*}$ are related to burial diagenesis of carbonates. The values of 
Table 1. Site 525: geochemical results.

\begin{tabular}{|c|c|c|c|c|c|c|c|c|c|c|c|c|c|c|c|c|c|c|c|}
\hline $\begin{array}{c}\text { Sample } \\
\text { (level in } \mathrm{cm} \text { ) }\end{array}$ & $\begin{array}{l}\mathrm{SiO}_{2} \\
(\%)\end{array}$ & $\begin{array}{c}\mathrm{Al}_{2} \mathrm{O}_{3} \\
(\%)\end{array}$ & $\begin{array}{l}\mathrm{CaO} \\
(\%)\end{array}$ & $\begin{array}{c}\mathrm{MgO} \\
(\%)\end{array}$ & $\begin{array}{c}\mathrm{Na}_{2} \mathrm{O} \\
(\%)\end{array}$ & $\begin{array}{l}\mathrm{K}_{2} \mathrm{O} \\
(\%)\end{array}$ & $\begin{array}{l}\mathrm{TiO}_{2} \\
(\%)\end{array}$ & $\begin{array}{l}\mathrm{Fe}_{2} \mathrm{O}_{3} \\
(\%)\end{array}$ & $\underset{(\mathrm{ppm})}{\mathrm{Mn}}$ & $\underset{(\mathrm{ppm})}{\mathrm{Zn}}$ & $\underset{(\mathrm{ppm})}{\mathrm{Li}}$ & $\begin{array}{c}\mathrm{Ni} \\
(\mathrm{ppm})\end{array}$ & $\underset{(\mathrm{ppm})}{\mathrm{Cr}}$ & $\underset{(\mathrm{ppm})}{\mathrm{Sr}}$ & $\begin{array}{c}\mathrm{Co} \\
(\mathrm{ppm})\end{array}$ & $\underset{(\mathrm{ppm})}{\mathrm{Cu}}$ & $\begin{array}{c}\mathrm{Pb} \\
(\mathrm{ppm})\end{array}$ & $\underset{(\mathrm{ppm})}{\mathrm{V}}$ & $\begin{array}{c}\mathrm{Cd} \\
(\mathrm{ppm})\end{array}$ \\
\hline \multicolumn{20}{|l|}{ Hole 525A } \\
\hline $3-3,100$ & 1.00 & 0.14 & 50.66 & 0.23 & 0.92 & 0.09 & 0.01 & 0.10 & 121 & 395 & 1 & 9 & 13 & 1,516 & 7 & 7 & 32 & 0 & 2 \\
\hline $6-2,40$ & 1.10 & 0.14 & 50.35 & 0.20 & 0.88 & 0.09 & 0.01 & 0.10 & 126 & 232 & i & 6 & 17 & 1,421 & 7 & 3 & 32 & 0 & 2 \\
\hline $8-4,50$ & 1.85 & 0.38 & 49.89 & 0.30 & 1.08 & 0.16 & 0.04 & 0.31 & 247 & 289 & 2 & 9 & 15 & 1,558 & 9 & 1 & 29 & 0 & 2 \\
\hline $11-2,55$ & 3.30 & 0.87 & 47.88 & 0.36 & 1.03 & 0.28 & 0.05 & 0.60 & 347 & 632 & 5 & 9 & 14 & 1,400 & 12 & 5 & 51 & 6 & 2 \\
\hline $13-2,50$ & 1.55 & 0.35 & 47.88 & 0.27 & 0.59 & 0.16 & 0.02 & 3.18 & 463 & 174 & 2 & 9 & 18 & 1,326 & 11 & 5 & 37 & 1 & 2 \\
\hline $15-2,63$ & 1.20 & 0.25 & 50.52 & 0.26 & 0.59 & 0.12 & 0.02 & 0.28 & 179 & 795 & 3 & 5 & 16 & 1,358 & 9 & 5 & 53 & 5 & 3 \\
\hline $17-1,55$ & 3.10 & 0.71 & 49.22 & 0.29 & 0.86 & 0.30 & 0.01 & 0.42 & 305 & 147 & 4 & 12 & 17 & 1,442 & 9 & 2 & 41 & 8 & 3 \\
\hline $20-1,50$ & 1.65 & 0.31 & 48.55 & 0.31 & 0.86 & 0.15 & 0.03 & 0.31 & 326 & 247 & 1 & 11 & 14 & 795 & 8 & 2 & 45 & 8 & 3 \\
\hline $22-2,50$ & 0.55 & 0.12 & 44.19 & 0.31 & 0.81 & 0.06 & 0.01 & 0.14 & 263 & 158 & i & 11 & 16 & 737 & 7 & 1 & 47 & 4 & 3 \\
\hline $24-2,50$ & 1.45 & 0.27 & 49.22 & 0.36 & 1.08 & 0.13 & 0.03 & 0.29 & 395 & 579 & 1 & 11 & 14 & 758 & 9 & 2 & 47 & 6 & 3 \\
\hline $26-1,50$ & 0.70 & 0.15 & 50.12 & 0.32 & 0.78 & 0.07 & 0.02 & 0.21 & 500 & 79 & 1 & 12 & 14 & 637 & 8 & 2 & 63 & 5 & 3 \\
\hline $28-3,30$ & 0.95 & 0.18 & 48.88 & 0.27 & 0.79 & 0.12 & 0.02 & 0.19 & 121 & 137 & i & 11 & 13 & 789 & 7 & 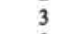 & 30 & 2 & 3 \\
\hline $31-2,50$ & 1.20 & 0.37 & 49.22 & 0.29 & 0.82 & 0.16 & 0.02 & 0.34 & 79 & 84 & 2 & 14 & 17 & 795 & 8 & 0 & 47 & 3 & 3 \\
\hline $35-2,55$ & 1.35 & 0.52 & 49.72 & 0.29 & 0.76 & 0.21 & 0.03 & 0.28 & 263 & 84 & 3 & 12 & 16 & 1,000 & 7 & 0 & 43 & 5 & 4 \\
\hline $36-3,84$ & 3.50 & 0.78 & 47.54 & 0.31 & 0.79 & 0.30 & 0.04 & 0.37 & 268 & 100 & 3 & 15 & 18 & 1,168 & 9 & 4 & 42 & 6 & 3 \\
\hline $38-4,28$ & 13.70 & 3.42 & 40.54 & 0.86 & 0.94 & 0.80 & 0.30 & 2.22 & 411 & 67 & 10 & 17 & 19 & 663 & 8 & 6 & 21 & 16 & 2 \\
\hline $39-2,105$ & 11.20 & 3.00 & 41.18 & 0.70 & 1.00 & 0.96 & 0.26 & 1.75 & 395 & 232 & 7 & 16 & 21 & 684 & 12 & 5 & 37 & 24 & 3 \\
\hline $39-5,99$ & 23.40 & 6.50 & 31.76 & 1.35 & 1.35 & 1.40 & 0.38 & 3.55 & 526 & 111 & 27 & 23 & 24 & 647 & 8 & 12 & 18 & 26 & $i$ \\
\hline $40-3,135$ & 27.40 & 7.75 & 27.81 & 1.45 & 1.15 & 2.11 & 0.43 & 4.12 & 405 & 105 & 22 & 15 & 26 & 600 & 8 & 2 & 22 & 137 & 2 \\
\hline $40-5,89$ & 15.30 & 4.25 & 38.13 & 0.85 & 1.04 & 1.16 & 0.30 & 2.50 & 516 & 68 & 14 & 12 & 15 & 721 & 5 & 4 & 21 & 16 & 2 \\
\hline $41-2,102$ & 16.70 & 4.59 & 34.72 & 0.93 & 1.15 & 1.48 & 0.33 & 2.68 & 716 & 116 & 13 & 12 & 25 & 705 & 7 & 4 & 53 & 48 & 2 \\
\hline $41-5,91$ & 15.30 & 4.14 & 37.78 & 1.04 & 0.91 & 0.95 & 0.33 & 2.29 & 547 & 69 & 14 & 9 & 17 & 789 & 6 & 4 & 36 & 11 & 1 \\
\hline $42-1,27$ & 10.95 & 3.14 & 41.63 & 0.80 & 0.74 & 0.63 & 0.25 & 1.64 & 611 & 48 & 10 & 7 & 14 & 821 & 8 & 4 & 45 & 11 & $\mathrm{i}$ \\
\hline $42-2,42$ & 10.15 & 2.83 & 41.98 & 0.78 & 0.71 & 0.56 & 0.20 & 1.62 & 684 & 50 & 9 & 13 & 15 & 900 & 8 & 0 & 45 & 16 & 2 \\
\hline $42-3,31$ & 14.80 & 4.06 & 36.66 & 1.04 & 0.59 & 1.20 & 0.24 & 2.27 & 837 & 153 & 12 & 17 & 24 & 742 & 9 & 5 & 48 & 29 & 2 \\
\hline $43-6,69$ & 23.65 & 5.91 & 31.76 & 1.26 & 1.28 & 1.54 & 0.47 & 3.15 & 884 & 60 & 14 & 8 & 23 & 716 & 5 & 4 & 42 & 21 & 0 \\
\hline $44-2,42$ & 38.15 & 9.81 & 17.73 & 2.88 & 1.69 & 1.26 & 1.19 & 6.33 & 458 & 305 & 40 & 16 & 39 & 505 & 11 & 42 & 31 & 232 & 1 \\
\hline $45-4,52$ & 24.05 & 5.67 & 29.30 & 1.67 & 1.48 & 1.29 & 0.33 & 3.79 & 1,100 & 379 & 24 & 6 & 20 & 768 & 4 & 4 & 46 & 32 & i \\
\hline $47-2,85$ & 23.00 & 4.96 & 31.24 & 1.51 & 1.33 & 1.05 & 0.38 & 3.57 & 974 & 358 & 20 & 4 & 21 & 711 & 5 & 3 & 47 & 36 & 1 \\
\hline $49-1,107$ & 31.55 & 7.49 & 22.36 & 2.10 & 1.53 & 2.02 & 0.59 & 5.33 & 653 & 247 & 20 & 12 & 43 & 574 & 5 & 27 & 39 & 101 & 1 \\
\hline $50-1,57$ & 64.25 & 5.02 & 10.08 & 1.00 & 1.08 & 1.36 & 0.27 & 2.57 & 247 & 126 & 9 & 15 & 28 & 274 & 9 & 6 & 27 & 46 & i \\
\hline $50-3,48$ & 49.90 & 6.05 & 15.33 & 1.41 & 1.21 & 1.66 & 0.39 & 3.79 & 432 & 16 & 11 & 9 & 28 & 40 & 6 & 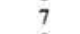 & 38 & 59 & 1 \\
\hline $51-1,20$ & 21.45 & 4.33 & 31.34 & 1.19 & 1.08 & 1.34 & 0.33 & 3.18 & 905 & 295 & 9 & 16 & 28 & 689 & 9 & 9 & 48 & 55 & 3 \\
\hline $51-3,13$ & 33.25 & 8.96 & 18.55 & 2.06 & 1.79 & 2.29 & 0.79 & 7.33 & 837 & 374 & 14 & 17 & 34 & 558 & 15 & 42 & 39 & 114 & 1 \\
\hline $52-3,109$ & 21.30 & 5.59 & 30.03 & 1.38 & 1.46 & 1.40 & 1.65 & 3.97 & 758 & 153 & 11 & 14 & 29 & 658 & 7 & 0 & 42 & 73 & 2 \\
\hline $52-4,142$ & 14.65 & 4.59 & 35.82 & 0.99 & 1.25 & 0.52 & 0.62 & 3.57 & 1,232 & 279 & 4 & 10 & 33 & 774 & 6 & 0 & 62 & 105 & 3 \\
\hline $52-5,129$ & 32.55 & 4.71 & 26.78 & 0.39 & 1.52 & 1.66 & 0.43 & 1.47 & 1,026 & 237 & 4 & 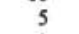 & 33 & 668 & 4 & 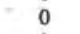 & 45 & - & 1 \\
\hline $53-1,107$ & 86.65 & 3.13 & 0.07 & 0.20 & 1.04 & 0.84 & 0.23 & 1.22 & 21 & 147 & 3 & 3 & 33 & 142 & 66 & 3 & 23 & 52 & 0 \\
\hline \multicolumn{20}{|l|}{ Hole 525B } \\
\hline $3-1,84$ & 0.95 & 0.33 & 48.35 & 0.28 & 1.08 & 0.14 & 0.0 & 0.2 & 1 & 168 & 2 & 12 & 16 & 1,332 & 7 & 8 & 26 & 4 & 3 \\
\hline $5-1,75$ & 1.20 & 0.32 & 49.22 & 0.27 & 0.8 & 0.12 & 0. & 0.2 & 153 & 79 & i & 11 & 15 & 1,421 & 8 & 8 & 36 & 3 & 3 \\
\hline $8-1,98$ & 0.65 & 0.25 & 48.55 & 0.27 & 0.88 & 0.10 & 0.02 & 0.19 & 147 & 53 & i & i1 & 16 & 1,453 & 8 & 3 & 32 & 4 & 3 \\
\hline $12-1,40$ & 0.65 & 0.17 & 51.89 & 0.27 & 0.91 & 0.08 & 0.02 & 0.18 & 111 & 37 & 2 & i & 8 & 1,421 & 5 & 1 & 7 & 0 & 2 \\
\hline $14-3,44$ & 0.95 & 0.17 & 50.32 & 0.24 & 0.79 & 0.08 & 0.0 & 0.1 & 12 & 26 & 1 & 0 & 7 & 1,474 & 4 & 1 & 23 & 2 & 3 \\
\hline $17-1,20$ & 0.20 & 0.1 & 50.72 & 0.2 & 0.7 & 0.07 & 0.0 & 0.1 & 111 & 32 & i & 0 & 13 & 1,474 & 3 & 0 & 27 & 3 & 2 \\
\hline $19-1,66$ & 1.05 & 0.26 & 51.02 & 0.24 & 0.84 & 0.10 & 0.02 & 0.16 & 126 & 21 & 2 & 7 & 11 & 1,442 & 3 & 1 & 18 & 4 & 3 \\
\hline $25-1,44$ & 1.70 & 0.43 & 49.42 & 0.31 & 1.04 & 0.15 & 0.03 & 0.97 & 258 & 58 & 3 & 11 & 14 & 1,200 & 4 & 0 & 19 & 6 & 2 \\
\hline $27-1,75$ & 1.05 & 0.26 & 49.89 & 0.24 & 0.79 & 0.09 & 0.02 & 0.19 & 184 & 26 & 2 & 4 & 12 & 1,158 & 3 & 0 & 18 & 5 & 2 \\
\hline
\end{tabular}

$\mathrm{Mg}^{*}(0.22)$ and $\mathrm{Fe}^{*}(0.63)$ are very close to the mean value of the clay minerals. The detrital components, especially the clay minerals, are important.

In upper Maestrichtian sediments, $D^{*}(0.57)$ is very close to the value characteristic of typical shales. $\mathrm{Si}^{*}$ (2.07) is typical of the values recorded in marine carbonates. Mn* is always positive, indicative of an open marine environment and perhaps of metal enrichment associated with the spreading center (see Chamley et al., this volume).

In the lower to upper Paleocene, $D^{*}(0.56)$ is close to the values recorded in typical shales. The values of $\mathrm{Si}^{*}$, $\mathrm{Fe}^{*}$, and $\mathrm{Mg} *$ are homogeneous with those of the upper Maestrichtian sediments, which is also indicative of an open marine environment. $\mathrm{Sr}$ * is typical of the values recorded in marine carbonates, though slightly lower in the upper Paleocene.

From upper Paleocene to Eocene, D* $(0.37)$ decreases with the progressive diminution of the continental influence, and Mn* (1.04) increases in response to the presence of an oxidizing environment (oxidizing water masses or volcanic events along the oceanic spreading center). Sr* is typical of marine carbonates. These values decrease slowly, suggesting a burial diagenesis of carbonates. The position of the site has always been above the CCD and perhaps above the lysocline.

From Oligocene to Pleistocene, D* $(0.44)$ increases slightly as Mn* decreases $(0.87)$. These values suggest a slight input of detrital materials. During early Miocene and late Miocene times, $\mathrm{Fe}^{*}$ and $\mathrm{Mg}^{*}$ values were very high but decreased thereafter. The occurrence of a strong volcanogenic input of ferromagnesian components is suggested. $\mathrm{Sr}^{*}$ (2.89) increases slightly in the Miocene section; this value is very close to those recorded in marine carbonates. The effects of burial diagenesis of carbonates are slight. The site has always been located above the $\mathrm{CCD}$, preventing any strong dissolution effect.

Site 529

\section{Lithology (Fig. 5)}

The sediments consist of carbonate oozes and chalks (Site 529 chapter), with cherts present in the lower Eo- 


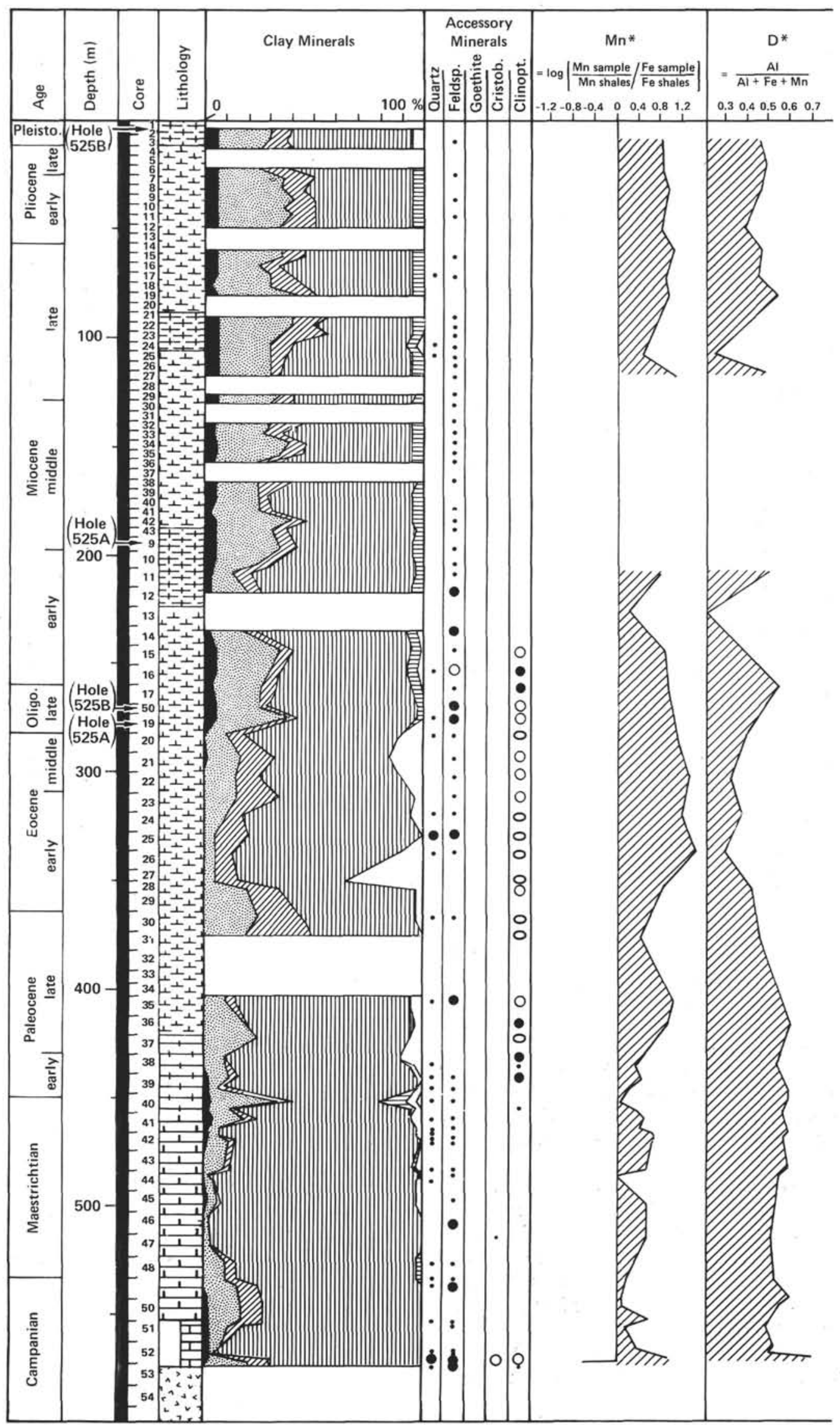

Figure 4. Site 525 results. 


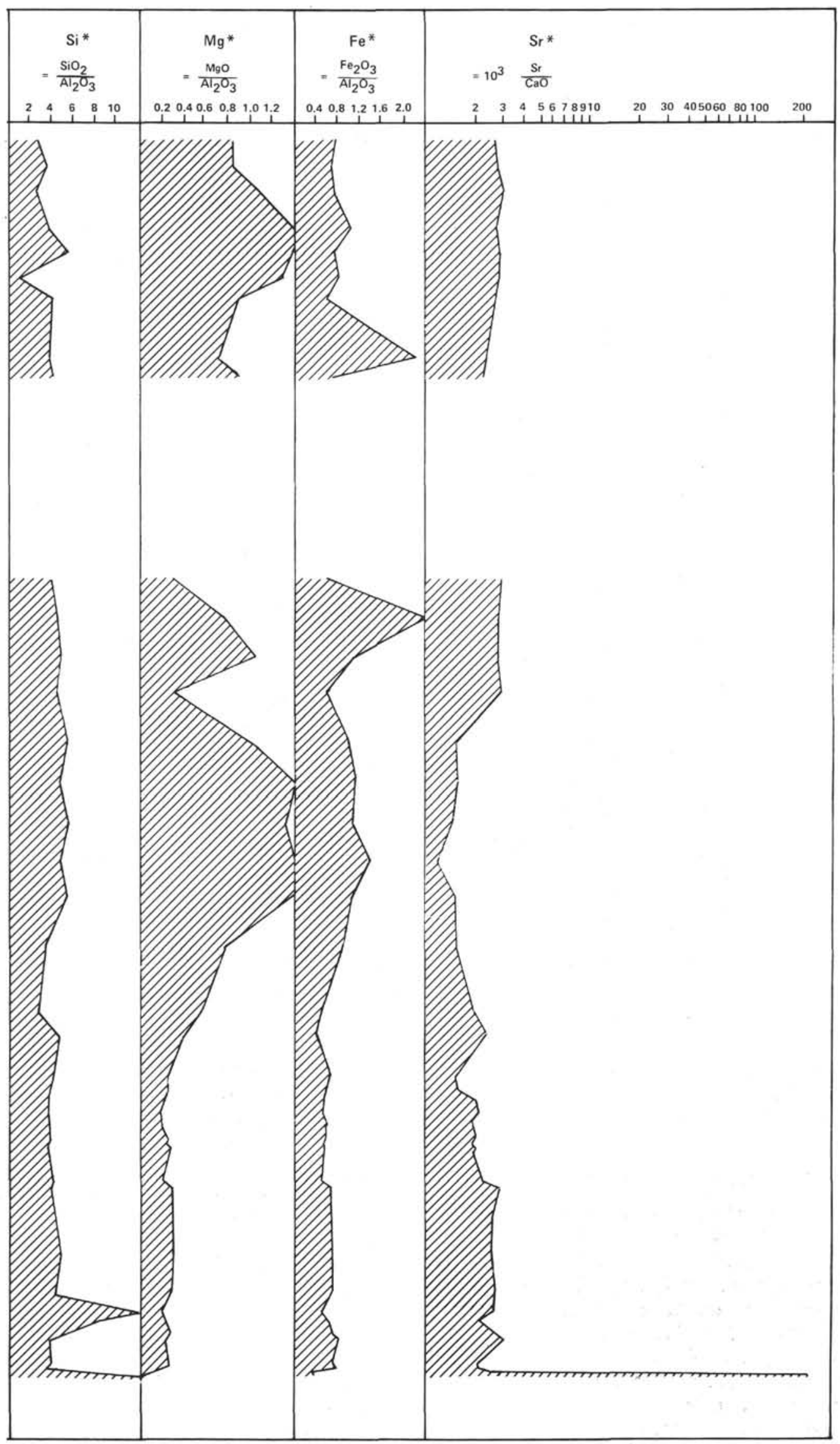

Figure 1. (Continued). 


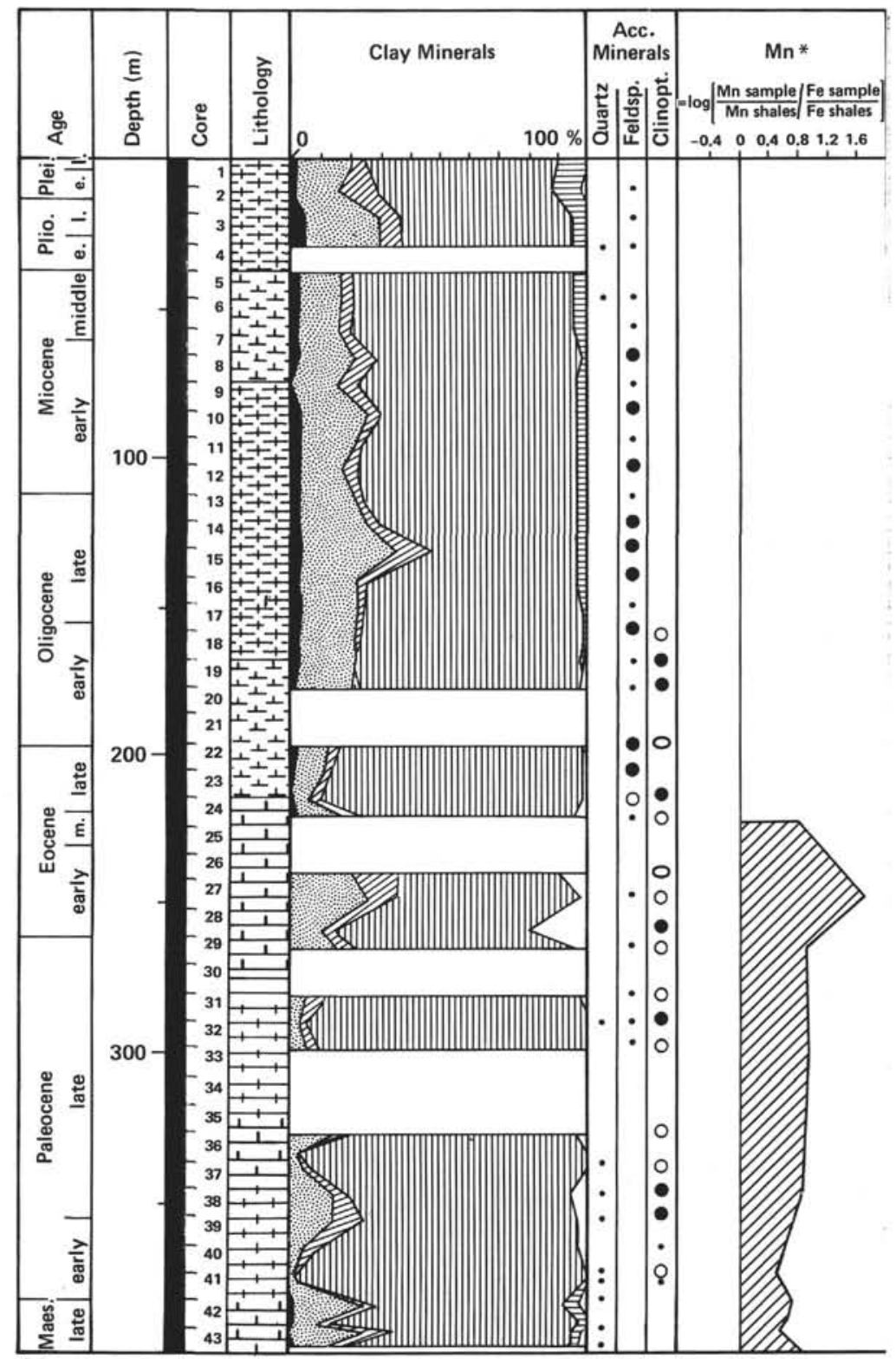

Figure 5. Site 529 results.

cene and Paleocene. Volcanic materials are particularly common in the basal Paleocene-Mastrichtian sequence. Erosional hiatuses and slump deposits occur frequently at this site.

\section{Clay Mineralogy (Fig. 5)}

In upper Maestrichtian to upper Paleocene sediments (Cores 43-35), chlorite (0-trace amounts), illite (trace amounts-25\%), mixed-layer clays $(0-10 \%)$, smectite $(60-95 \%)$, kaolinite $(0-5 \%)$, and palygorskite $(0-5 \%)$ are present, accompanied by quartz and clinoptilolite. This clay assemblage reflects the influence of rock erosion and moderate weathering, as well as of sediment supplied from confined basins. The importance of flat coastal lowlands where smectite forms is very apparent.

In upper Paleocene and lower Eocene sediments (Cores 33-26), palygorskite (0-20\%) and mixed-layer clays (trace amounts-15\%) increase, whereas the abun- dance of smectite diminishes (50-90\%). Illite (trace amounts-25\%) is also present. Chlorite and kaolinite disappear. Clay minerals are accompanied by quartz, feldspar, and clinoptilolite. The importance of detrital supplies both from moderately weathered rocks and from confined coastal basins increases during this period.

From the upper Eocene up (Cores 24-1), chlorite $(0-5 \%)$, illite $(5-25 \%)$, mixed-layers $(0-15 \%)$, smectite $(45-85 \%)$, kaolinite $(0-10 \%)$, and palygorskite (0-trace amounts) are present, accompanied by quartz, feldspar, and clinoptilolite.

\section{Geochemistry (Fig. 5 and Table 2)}

We studied only the base of the sedimentary section (upper Maestrichtian-middle Eocene). In upper Maestrichtian sediments, $\mathrm{D}^{*}(0.59)$ is very close to the value characteristic of typical shales. The values of $\mathrm{Si}^{*}(3.40)$ suggest the presence of only clay minerals in the sedi- 


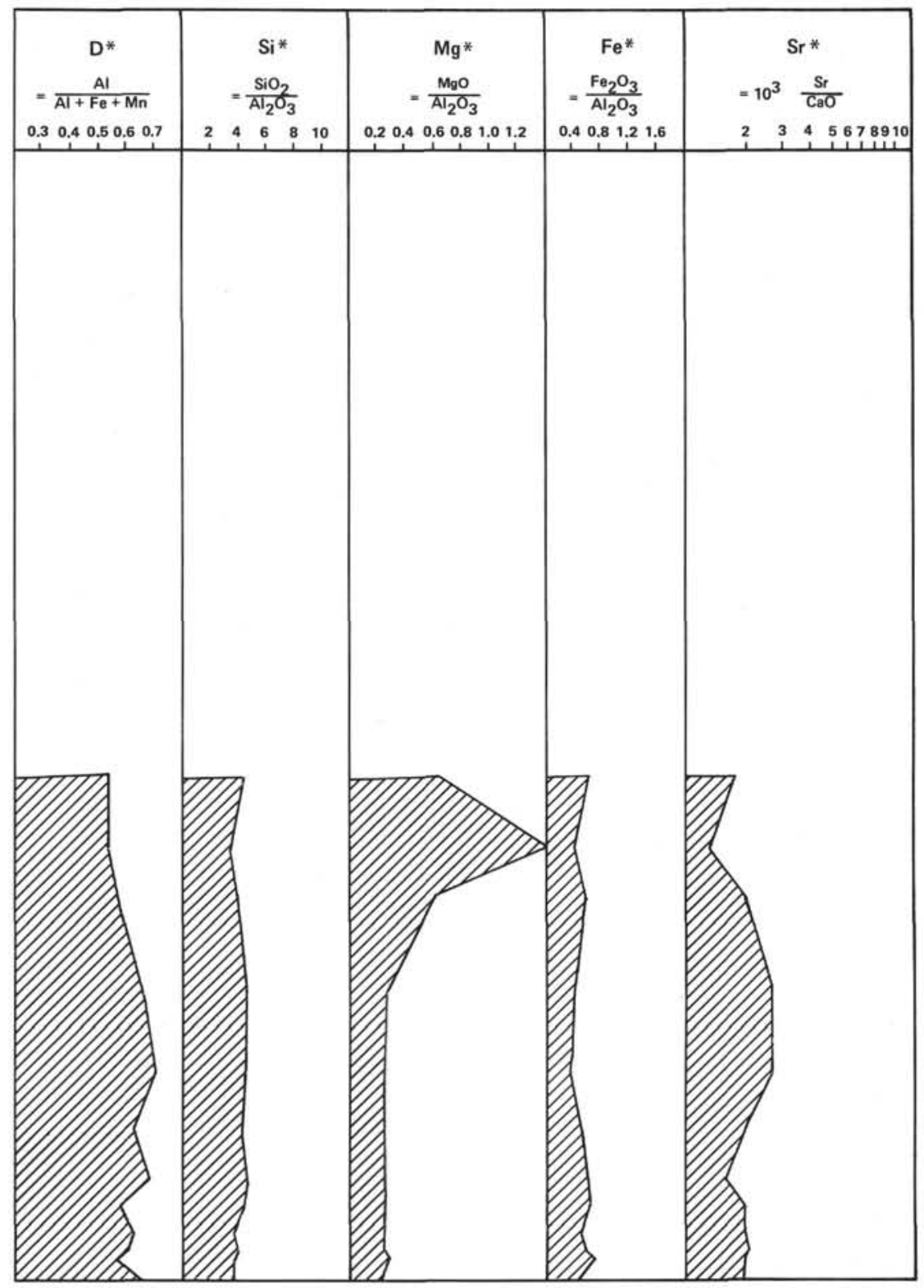

Figure 5. (Continued).

Table 2. Site 529: geochemical results.

\begin{tabular}{|c|c|c|c|c|c|c|c|c|c|c|c|c|c|c|c|c|c|c|c|}
\hline $\begin{array}{l}\text { Core/Section } \\
\text { (level in } \mathrm{cm} \text { ) }\end{array}$ & $\begin{array}{l}\mathrm{SiO}_{2} \\
(\%)\end{array}$ & $\underset{(\%)}{\mathrm{Al}_{2} \mathrm{O}_{3}}$ & $\begin{array}{l}\mathrm{CaO} \\
(\%)\end{array}$ & $\begin{array}{c}\mathrm{MgO} \\
(\%)\end{array}$ & $\underset{(\%)}{\mathrm{Na}_{2} \mathrm{O}}$ & $\begin{array}{l}\mathrm{K}_{2} \mathrm{O} \\
(\%)\end{array}$ & $\begin{array}{l}\mathrm{TiO}_{2} \\
(\%)\end{array}$ & $\begin{array}{c}\mathrm{Fe}_{2} \mathrm{O}_{3} \\
(\%)\end{array}$ & $\underset{(\mathrm{ppm})}{\mathrm{Mn}}$ & $\underset{(\mathrm{ppm})}{\mathrm{Zn}}$ & $\underset{(\mathrm{ppm})}{\mathrm{Li}}$ & $\begin{array}{c}\mathrm{Ni} \\
(\mathrm{ppm})\end{array}$ & $\underset{(\mathrm{ppm})}{\mathrm{Cr}}$ & $\underset{(\mathrm{ppm})}{\mathrm{Sr}}$ & $\begin{array}{c}\text { Co } \\
\text { (ppm) }\end{array}$ & $\underset{(\mathrm{ppm})}{\mathrm{Cu}}$ & $\begin{array}{c}\mathrm{Pb} \\
\text { (ppm) }\end{array}$ & $\underset{(\mathrm{ppm})}{\mathrm{V}}$ & $\begin{array}{c}\mathrm{Cd} \\
(\mathrm{ppm})\end{array}$ \\
\hline $24-5,60$ & 2.35 & 0.57 & 48.21 & 0.36 & 0.92 & 0.18 & 0.07 & 0.36 & 237 & 42 & 2 & 7 & 11 & 816 & 8 & 6 & 26 & 5 & 3 \\
\hline $27-4,50$ & 0.55 & 0.17 & 49.28 & 0.30 & 0.56 & 0.10 & 0.01 & 0.07 & 253 & 58 & 1 & 6 & 9 & 632 & 10 & 4 & 32 & 5 & 3 \\
\hline $29-3,44$ & 2.00 & 0.53 & 48.21 & 0.32 & 0.67 & 0.20 & 0.03 & 0.29 & 158 & 53 & 3 & 5 & 11 & 874 & 8 & 5 & 35 & 5 & 3 \\
\hline $33-1,84$ & 6.30 & 1.47 & 44.13 & 0.36 & 0.71 & 0.42 & 0.10 & 0.54 & 363 & 53 & 6 & 7 & 14 & 1,079 & 7 & 11 & 29 & 12 & 2 \\
\hline $36-1,58$ & 8.05 & 1.95 & 42.85 & 0.47 & 0.67 & 0.43 & 0.10 & 0.61 & 389 & 74 & 7 & 15 & 15 & 1,037 & 9 & 17 & 34 & 14 & 2 \\
\hline $38-1,24$ & 7.70 & 1.93 & 43.83 & 0.47 & 0.72 & 0.45 & 0.12 & 0.86 & 521 & 58 & 6 & 10 & 15 & 779 & 7 & 10 & 32 & 18 & 2 \\
\hline $40-1,35$ & 14.40 & 3.25 & 39.53 & 0.70 & 0.98 & 0.86 & 0.27 & 1.76 & 642 & 92 & 8 & 14 & 17 & 574 & 7 & 8 & 47 & 63 & 1 \\
\hline $41-1,110$ & 20.05 & 4.84 & 34.63 & 1.05 & 1.26 & 1.19 & 0.37 & 2.83 & 663 & 91 & 15 & 22 & 22 & 605 & 9 & 10 & 45 & 63 & 1 \\
\hline $41-1,120$ & 17.95 & 1.47 & 34.82 & 1.07 & 0.89 & 0.98 & 0.33 & 2.04 & 968 & 147 & 14 & 16 & 27 & 458 & 12 & 14 & 39 & 47 & 2 \\
\hline $42-2,73$ & 12.30 & 3.65 & 39.91 & 0.76 & 0.78 & 1.05 & 0.23 & 1.64 & 679 & 55 & 8 & 11 & 19 & 705 & 8 & 4 & 47 & 63 & 1 \\
\hline $42-5,73$ & 12.05 & 3.40 & 40.40 & 0.73 & 0.74 & 0.87 & 0.23 & 1.69 & 605 & 59 & 9 & 17 & 18 & 726 & 9 & 7 & 47 & 79 & 1 \\
\hline $43-1,70$ & 10.00 & 2.95 & 42.68 & 0.70 & 0.61 & 0.86 & 0.19 & 1.79 & 505 & 56 & 6 & 8 & 14 & 758 & 9 & 2 & 52 & 84 & 1 \\
\hline $00-0,00$ & 00.00 & 0.00 & 00.00 & 0.00 & 0.00 & 0.00 & 0.00 & 0.00 & 605 & 000 & 00 & 7 & 16 & 711 & 6 & 6 & 43 & 24 & 2 \\
\hline
\end{tabular}


ment. $\mathrm{Fe}^{*}$ and $\mathrm{Mg}^{*}$ increase and decrease simultaneously-owing, almost certainly, to volcanic events in the rift area.

$\mathrm{Sr}^{*}(1.77)$ is typical of the values recorded in marine carbonates and is probably related to burial diagenesis. Marine carbonates are not subjected to dissolution. $\mathrm{Mn}^{*}(0.62)$ is always positive, which is indicative of an open marine environment and, perhaps, of metal enrichment related to the rift (see Chamley et al., this volume). At the Cretaceous/Tertiary boundary, the geochemical record of the sediment reflects the variations of the clay minerals and the influence of volcanogenic materials. During the Paleocene, the geochemical parameters of the sediments are constant $\left(\mathrm{D}^{*}=0.61 ; \mathrm{Si}^{*}\right.$ $=4.13$ ). $\mathrm{Sr}^{*}$ is typical of marine carbonates. They increase in the upper Paleocene and then decrease upward. This trend was apparently induced by a slight dissolution of carbonates during this time.

From lower to middle Eocene, the highly positive value of $\mathrm{Mn}^{*}(1.23)$ is characteristic of an oxidizing environment. $\mathrm{D}^{*}$ decreases slightly $(0.53)$, suggesting a weaker influence of the terrigenous components. $\mathrm{Si}^{*}$ (3.68) is very close to the composition of typical detrital shales, without any biogenic or volcanogenic siliceous influence. High positive $\mathrm{Mg}^{*}(1.20)$ and $\mathrm{Fe}^{*}(0.52)$ may be caused by abundant ferromagnesian components. $\mathrm{Sr}^{*}$ (1.49) indicates the presence of relatively well preserved marine carbonates.

\section{Site 528 (Holes 528 and 528A)}

\section{Lithology (Fig. 6)}

The sediments recovered comprise nannofossil chalk and ooze, foraminiferal-nannofossil ooze, and chalk (Site 528 chapter) from upper Paleocene to Pleistocene. This sedimentation is interrupted by volcanogenic sandstones and claystones, interpreted as turbidity current deposits during early Paleocene and middle Maestrichtian time.

\section{Clay Mineralogy (Fig. 6)}

The middle Maestrichtian sediments intercalated in basalts show the presence of chlorite (up to trace amounts), illite (10-25\%), mixed-layers (5-20\%), smectite $(45-80 \%)$, kaolinite $(0-5 \%)$, and palygorskite (up to trace amounts). There is no evidence of the influence of volcanism on the clay mineral assemblage (Chamley et al., this volume).

From middle Maestrichtian to upper Paleocene (Cores 528-38 to 528-26), the clay assemblage includes chlorite $(0-5 \%)$, illite $(10-35 \%)$, mixed layers $(5-15 \%)$, smectite $(35-70 \%)$, kaolinite $(0-10 \%)$, palygorskite $(0-10 \%)$. Quartz, feldspar, and goethite are also present. This clay mineral assemblage contains particles from the direct erosion of rocks and from moderate weathering. However, in Cores 528-30 and 528-31, the sediment consists of almost $100 \%$ well-crystallized smectite. Considering the abruptness of mineralogical change, the smectite is probably volcanogenic in origin; the emergent parts of the Walvis Ridge (Chamley et al., this volume) are the most likely source.
From upper Paleocene to upper Eocene (Cores 528-25 to 528-15) illite (5-15\%), mixed-layers (trace amounts$10 \%)$, smectite $(35-75 \%)$, and palygorskite $(0-35 \%)$ are present (Plate 1), accompanied by feldspar and clinoptilolite. As at previous sites, this unit reflects the influence of moderate continental weathering and confined coastal basins on sedimentation.

From upper Eocene upward (Cores 528-14-528-2 and 528-A, Cores $28-1)$, chlorite $(0-5 \%)$, illite $(10-25 \%)$, mixed-layer clays (trace amounts-10\%), and kaolinite (trace amounts-5\%) increase, smectite (55-70\%) diminishes, and palygorskite occurs episodically in trace amounts. Quartz and feldspar are also present. The influence of the Cenozoic climate cooling on clay particles is very comparable with the record at Site 529 .

\section{Geochemistry (Fig. 6 and Table 3)}

During middle Maestrichtian time, Mn* values (0.68) are characteristic of oxidizing sedimentation. However, this value is low compared to those of the sediments overlying the basalts (Maillot and Robert, 1980). D* (0.48) suggests a slight influence by terrigenous components. $\mathrm{Si}^{*}(3.94)$ is close to the mean value for clay minerals. $\mathrm{Fe}^{*}$, very high during middle Maestrichtian, decreases thereafter. $\mathrm{Sr}^{*}$ (2.06), typical of the values recorded in marine carbonates, includes the effects of burial diagenesis of carbonates and perhaps of some dissolution of carbonates. During the late Maestrichtian, $\mathrm{Mn}^{*}(0.90)$ is highly positive and $\mathrm{Fe}^{*}(0.49)$ decreases; $\mathrm{Mn}$ is more oxidizing than $\mathrm{Fe}$. These values are almost certainly related to volcanic events in the rift area, which were very influential during the Maestrichtian and became less so when Site 528 edged away from the rift area. $D^{*}(0.58)$ increases slightly, suggesting the greater influence of terrigenous components. $\mathrm{Sr}^{*}(2.01)$ is typical of the values recorded in marine carbonates and reveals what may be the effects of burial diagenesis and a slight dissolution of carbonates.

The geochemical record of the Cretaceous/Tertiary boundary suggests only major modifications in the clay assemblage (Chamley et al., this volume).

In the lower Paleocene, $\mathrm{D}^{*}(0.54), \mathrm{Si}^{*}$ (3.44), $\mathrm{Mg}$ * $(0.20)$, and $\mathrm{Fe}^{*}(0.62)$ suggest homogeneous deposits of sediment in oxidizing conditions $\left(\mathrm{Mn}^{*}=0.69\right)$. $\mathrm{Sr}^{*}$ decreases, a trend which can be explained by the lack of dissolution, probably related to the occurrence of slumps.

At the beginning of the upper Paleocene, $D^{*}$ increases slightly $(0.66)$, suggesting a greater influence of terrigenous components. $\mathrm{Si}^{*}, \mathrm{Mg}^{*}$, and $\mathrm{Fe}^{*}$ variations can be explained by the chemical composition of clay minerals. Mn* is strongly positive (1.11) in response to the presence of an oxidizing environment, related perhaps to volcanic events along the mid-oceanic ridge or to the presence of oxidized water masses. $\mathrm{Sr}^{*}(2.30)$ increases, indicating dissolution of calcareous sediments; it has been suggested that Site 528 came near the CCD by subsidence of the seafloor or by a rise in the CCD itself. From the uppermost Paleocene to the lower Oligocene, $\mathrm{Mn}^{*}(1.02)$ is highly positive in response to the presence of an oxidizing environment. $\mathrm{D}^{*}(0.50)$ dimin- 
Table 3. Site 528: geochemical results.

\begin{tabular}{|c|c|c|c|c|c|c|c|c|c|c|c|c|c|c|c|c|c|c|c|}
\hline $\begin{array}{l}\text { Core/Section } \\
\text { (level in cm) }\end{array}$ & $\underset{(\%)}{\mathrm{SiO}_{2}}$ & $\begin{array}{l}\mathrm{Al}_{2} \mathrm{O}_{3} \\
(\%)\end{array}$ & $\begin{array}{l}\mathrm{CaO} \\
(\%)\end{array}$ & $\begin{array}{l}\mathrm{MgO} \\
(\%)\end{array}$ & $\begin{array}{c}\mathrm{Na}_{2} \mathrm{O} \\
(\%)\end{array}$ & $\begin{array}{l}\mathrm{K}_{2} \mathrm{O} \\
(\%)\end{array}$ & $\begin{array}{l}\mathrm{TiO}_{2} \\
(\%)\end{array}$ & $\begin{array}{c}\mathrm{Fe}_{2} \mathrm{O}_{3} \\
(\%)\end{array}$ & $\underset{(\mathrm{ppm})}{\mathrm{Mn}}$ & $\underset{(\mathrm{ppm})}{\mathrm{Zn}}$ & $\underset{(\mathrm{ppm})}{\mathrm{Li}}$ & $\underset{(\mathrm{ppm})}{\mathrm{Ni}}$ & $\underset{(\mathrm{ppm})}{\mathrm{Cr}}$ & $\begin{array}{c}\mathrm{Sr} \\
(\mathrm{ppm})\end{array}$ & $\begin{array}{c}\text { Co } \\
\text { (ppm) }\end{array}$ & $\underset{(\mathrm{ppm})}{\mathrm{Cu}}$ & $\underset{\text { (ppm) }}{\mathrm{Pb}}$ & $\underset{(\mathrm{ppm})}{\mathrm{V}}$ & $\underset{(\mathrm{ppm})}{\mathrm{Cd}}$ \\
\hline \multicolumn{20}{|l|}{ Hole 528} \\
\hline $1-2,70$ & 2.55 & 0.64 & 47.54 & 0.31 & 1.08 & 0.15 & 0.03 & 0.40 & 321 & 63 & 3 & 8 & 14 & 1,526 & 3 & 8 & 47 & 8 & 4 \\
\hline $1-5,70$ & 2.40 & 0.60 & 48.21 & 0.31 & 1.10 & 0.16 & 0.04 & 0.36 & 337 & 68 & 3 & 12 & 51 & 1,574 & 6 & 7 & 39 & 9 & 4 \\
\hline $2-1,20$ & 6.35 & 2.14 & 44.53 & 0.52 & 0.77 & 0.54 & 0.11 & 1.07 & 789 & 68 & 8 & 23 & 20 & 1,558 & 9 & 10 & 25 & 16 & 3 \\
\hline $4-1,20$ & 4.55 & 1.47 & 46.70 & 0.40 & 0.81 & 0.37 & 0.08 & 0.79 & 747 & 58 & 6 & 16 & 14 & 1,584 & 8 & 8 & 24 & 15 & 4 \\
\hline $5-4,53$ & 7.45 & 2.12 & 44.70 & 0.48 & 0.82 & 0.60 & 0.10 & 1.04 & 1,179 & 53 & 9 & 28 & 17 & 1,421 & 15 & 20 & 29 & 18 & 3 \\
\hline $7-1,50$ & 4.25 & 1.38 & 46.84 & 0.32 & 0.78 & 0.39 & 0.07 & 0.66 & 442 & 58 & 6 & 12 & 17 & 1,410 & 7 & 6 & 26 & 15 & 3 \\
\hline $8-4,60$ & 4.45 & 1.49 & 45.87 & 0.36 & 0.71 & 0.42 & 0.08 & 0.72 & 579 & 53 & 5 & 9 & 13 & 1,495 & 8 & 8 & 35 & 13 & 3 \\
\hline $10-1,60$ & 4.35 & 1.34 & 46.81 & 0.37 & 0.86 & 0.39 & 0.07 & 0.66 & 458 & 58 & 6 & 19 & 17 & 1,500 & 8 & 7 & 31 & 13 & 3 \\
\hline $12-5,91$ & 2.85 & 0.57 & 51.19 & 0.27 & 0.65 & 0.21 & 0.04 & 0.34 & 200 & 47 & 3 & 6 & 16 & 1,179 & 5 & 0 & 27 & 8 & 3 \\
\hline $15-2,80$ & 4.50 & 1.53 & 44.86 & 0.50 & 0.81 & 0.45 & 0.08 & 1.00 & 816 & 42 & 5 & 17 & 13 & 1,126 & 13 & 18 & 55 & 13 & 2 \\
\hline $16-4,102$ & 1.85 & 0.47 & 49.55 & 0.33 & 0.73 & 0.19 & 0.03 & 0.43 & 532 & 32 & 2 & 10 & 8 & 774 & 12 & 8 & 45 & 9 & 3 \\
\hline $18-1,70$ & 1.40 & 0.32 & 49.38 & 0.32 & 0.73 & 0.15 & 0.03 & 0.36 & 563 & 42 & 1 & 9 & 9 & 689 & 11 & 8 & 58 & 12 & 3 \\
\hline $20-1,70$ & 1.30 & 0.42 & 48.88 & 0.26 & 0.65 & 0.16 & 0.02 & 0.21 & 358 & 26 & 1 & 8 & 11 & 737 & 11 & 11 & 44 & 7 & 3 \\
\hline $22-1,87$ & 1.45 & 0.53 & 48.88 & 0.30 & 0.73 & 0.18 & 0.02 & 0.33 & 242 & 47 & 3 & 17 & 16 & 858 & 12 & 8 & 38 & 4 & 2 \\
\hline $23-4,78$ & 2.80 & 0.74 & 47.37 & 0.30 & 0.63 & 0.19 & 0.03 & 0.26 & 221 & 58 & 6 & 17 & 9 & 947 & 8 & 9 & 37 & 5 & 2 \\
\hline $25-1,101$ & 3.45 & 1.15 & 46.67 & 0.35 & 0.71 & 0.30 & 0.05 & 0.40 & 284 & 37 & 6 & 7 & 8 & 1,137 & 5 & 19 & 51 & 9 & 3 \\
\hline $28-1,21$ & 3.85 & 1.17 & 46.20 & 0.34 & 0.61 & 0.34 & 0.06 & 0.33 & 921 & 42 & 5 & 8 & 9 & 1,132 & 5 & 9 & 42 & 18 & 3 \\
\hline $30-2,83$ & 11.55 & 3.36 & 40.58 & 0.93 & 0.78 & 0.96 & 0.25 & 2.33 & 1,105 & 84 & 12 & 21 & 15 & 537 & 12 & 27 & 45 & 32 & 1 \\
\hline $30-4,45$ & 17.20 & 5.03 & 33.48 & 1.24 & 1.11 & 1.14 & 1.17 & 2.93 & 1,316 & 84 & 23 & 22 & 17 & 484 & 19 & 42 & 21 & 34 & 3 \\
\hline $31-2,120$ & 19.70 & 5.44 & 33.13 & 1.35 & 1.11 & 1.64 & 0.30 & 3.36 & 1,553 & 108 & 22 & 26 & 19 & 495 & 13 & 40 & 53 & 53 & 0 \\
\hline $31-5,138$ & 19.55 & 5.97 & 32.01 & 1.42 & 1.15 & 1.69 & 0.43 & 3.50 & 1,379 & 129 & 25 & 29 & 18 & 600 & 12 & 47 & 45 & 47 & 0 \\
\hline $32-1,101$ & 11.90 & 3.78 & 38.80 & 0.83 & 0.69 & 1.17 & 0.54 & 1.64 & 795 & 58 & 11 & 15 & 18 & 753 & 7 & 13 & 60 & 42 & 2 \\
\hline $32-5,67$ & 12.30 & 3.67 & 38.83 & 0.80 & 0.81 & 1.37 & 0.23 & 2.14 & 684 & 66 & 10 & 13 & 16 & 768 & 10 & 5 & 45 & 58 & 1 \\
\hline $33-1,107$ & 22.55 & 6.50 & 30.15 & 1.45 & 0.94 & 1.96 & 0.36 & 3.57 & 916 & 104 & 23 & 15 & 26 & 663 & 8 & 7 & 43 & 74 & 0 \\
\hline $33-5,71$ & 13.80 & 4.14 & 38.30 & 0.98 & 0.82 & 1.29 & 0.23 & 2.36 & 1,221 & 86 & 15 & 17 & 20 & 774 & 9 & 8 & 47 & 74 & 1 \\
\hline $34-1,57$ & 12.10 & 3.72 & 38.80 & 0.84 & 0.71 & 1.10 & 0.22 & 1.86 & 1,010 & 58 & 13 & 14 & 16 & 821 & 7 & 10 & 35 & 37 & 2 \\
\hline $35-1,53$ & 7.05 & 2.42 & 42.85 & 0.58 & 0.66 & 0.78 & 0.13 & 0.79 & 742 & 47 & 7 & 10 & 15 & 874 & 5 & 9 & 35 & 29 & 2 \\
\hline $36-1,132$ & 5.95 & 1.93 & 44.36 & 0.53 & 0.60 & 0.63 & 0.12 & 0.90 & 1,705 & 37 & 6 & 11 & 13 & 832 & 5 & 4 & 61 & 18 & 3 \\
\hline $36-3,34$ & 6.20 & 2.02 & 43.86 & 0.52 & 0.62 & 0.66 & 0.13 & 0.83 & 2,326 & 53 & 5 & 9 & - & 879 & 6 & 10 & 50 & - & 2 \\
\hline $37-1,140$ & 19.60 & 5.54 & 31.74 & 1.49 & 0.89 & 1.81 & 0.25 & 2.79 & 2,705 & 63 & 16 & 4 & 27 & 611 & 9 & 0 & 19 & 52 & 2 \\
\hline $37-5,54$ & 14.25 & 4.18 & 36.33 & 1.04 & 0.71 & 1.52 & 0.25 & 2.19 & 1,947 & 58 & 12 & 12 & 24 & 716 & 11 & 9 & 34 & 23 & 3 \\
\hline $38-2,62$ & 20.50 & 5.67 & 30.30 & 1.61 & 0.91 & 1.93 & 0.35 & 3.43 & 2,384 & 74 & 19 & 13 & 35 & 689 & 10 & 19 & 47 & 51 & 2 \\
\hline $39-1,27$ & 18.25 & 5.06 & 32.74 & 1.31 & 0.86 & 1.70 & 0.35 & 3.33 & 2,926 & 68 & 14 & 28 & 26 & 647 & 14 & 13 & 37 & 37 & 3 \\
\hline $42-3,103$ & 25.15 & 6.73 & 26.25 & 2.12 & 0.98 & 2.05 & 0.48 & 4.79 & 3,000 & 105 & 17 & 20 & 34 & 500 & 13 & 31 & 42 & 74 & 2 \\
\hline $43-1,98$ & 19.20 & 4.84 & 31.64 & 1.87 & 0.91 & 1.42 & 0.32 & 3.72 & 2,232 & 79 & 18 & 9 & 23 & 684 & 11 & 27 & 46 & 52 & 2 \\
\hline $44-1,64$ & 22.35 & 5.78 & 27.96 & 1.79 & 0.81 & 1.71 & 0.37 & 4.50 & 2,237 & 79 & 16 & 24 & 33 & 505 & 8 & 32 & 24 & 47 & 2 \\
\hline $46-2,46$ & 24.25 & 5.61 & 28.46 & 1.91 & 1.13 & 1.64 & 0.40 & 4.65 & 1,868 & 79 & 19 & 12 & 26 & 642 & 11 & 25 & 24 & 49 & 2 \\
\hline $46-5,54$ & 20.75 & 4.67 & 31.47 & 1.49 & 0.91 & 1.64 & 0.37 & 4.43 & 1,884 & 63 & 14 & 14 & 27 & 642 & 11 & 28 & 39 & 53 & 2 \\
\hline \multicolumn{20}{|l|}{ Hole $528 \mathrm{~A}$} \\
\hline $2-1,28$ & 2.65 & 0.87 & 47.84 & 0.40 & 1.18 & 0.22 & 0.03 & 0.54 & 416 & 32 & 4 & 14 & 16 & 1,600 & 7 & 13 & 42 & 14 & 3 \\
\hline $5-3,49$ & 1.20 & 0.34 & 48.68 & 0.27 & 0.91 & 0.12 & 0.02 & 0.19 & 284 & 21 & 2 & 13 & 15 & 1,458 & 6 & 10 & 31 & 3 & 3 \\
\hline $8-1,60$ & 1.35 & 0.26 & 48.55 & 0.27 & 0.98 & 0.11 & 0.01 & 0.07 & 221 & 21 & 1 & 3 & 11 & 1,468 & 6 & 7 & 46 & 4 & 2 \\
\hline $11-1,60$ & 1.10 & 0.30 & 48.21 & 0.29 & 0.91 & 0.15 & 0.02 & 0.07 & 211 & 21 & 1 & 4 & 12 & 1,337 & 7 & 5 & 39 & 6 & 3 \\
\hline $16-1,100$ & 0.70 & 0.25 & 48.85 & 0.27 & 1.01 & 0.15 & 0.01 & 0.29 & 268 & 21 & 2 & 4 & 11 & 1,432 & 8 & 3 & 40 & 8 & 3 \\
\hline $21-1,88$ & 1.00 & 0.40 & 47.88 & 0.27 & 0.78 & 0.15 & 0.02 & 0.26 & 300 & 26 & 2 & 6 & 12 & 1,337 & 8 & 3 & 42 & 9 & 2 \\
\hline $25-1,98$ & 1.50 & 0.53 & 48.45 & 0.29 & 0.71 & 0.17 & 0.02 & 0.33 & 405 & 26 & 3 & 10 & 17 & 1,000 & 12 & 8 & 28 & 4 & 2 \\
\hline
\end{tabular}

ishes with decreasing continental influence, and $\mathrm{Si}^{*}$ (3.62) is typical of the composition of detrital shales. $\mathrm{Sr}^{*}$ increases (1.56) from the uppermost Paleocene to the lower Eocene and is 2.67 from the middle Eocene to the lower Oligocene. During the latter interval, the carbonates are dissolved, as demonstrated by LePichon et al. (1978) and van Andel et al. (1977).

From the upper Oligocene to the Pleistocene, sedimentation is very homogeneous $\left(\mathrm{D}^{*}=0.55 ; \mathrm{Si}^{*}=3.38\right.$; $\mathrm{Mg}^{*}=0.56$; and $\left.\mathrm{Fe}^{*}=0.56\right) . \mathrm{Mn}^{*}$ is high $(1.08)$ in response to the presence of an oxidizing environment. Upper Oligocene and lower-middle Miocene sediments show a slight increase of $\mathrm{Sr}^{*}$ (3.05) resulting from a greater dissolution of the carbonates.

\section{Site $\mathbf{5 2 7}$}

\section{Lithology (Fig. 7)}

The dominant lithology consists of nannofossil ooze and chalk, clayey nannofossil ooze and chalk, and nannofossil clay (Site 527 chapter). At the beginning of the upper Maestrichtian, the sequence is composed of interbedded basalts and sediments.

\section{Clay Mineralogy (Fig. 7)}

Sediments interbedded in basalts contain a clay assemblage composed of chlorite (trace amounts) illite $(40 \%)$, mixed-layers $(15 \%)$, smectite $(45 \%)$, and trace amounts of chlorite, kaolinite, and palygorskite. Clay particles do not show any influence of volcanism (Chamley et al., this volume).

From upper Maestrichtian to upper Paleocene (Cores $38-27)$, chlorite $(0-10 \%)$, illite $(5-55 \%)$, mixed-layer clays (trace amounts-25\%), smectite (10-70\%), kaolinite (trace amounts-10\%), palygorskite $(0-15 \%)$, and sepiolite ( 0 -trace amounts) are present, accompanied by quartz, feldspar, and goethite. This clay assemblage reflects principally a major influence of the direct erosion of rocks and of moderate weathering on the clay fraction.

From upper Paleocene to upper Eocene (Cores 26-16), clay minerals (Plate 1$)$ include chlorite $(0-5 \%)$, illite $(0-35 \%)$, mixed-layer clays $(0-10 \%)$, smectite (45$100 \%$ ), kaolinite (0-trace amounts), and palygorskite $(0-10 \%)$. Feldspar and clinoptilolite are also present. As at previous sites, the influence of moderate continental 


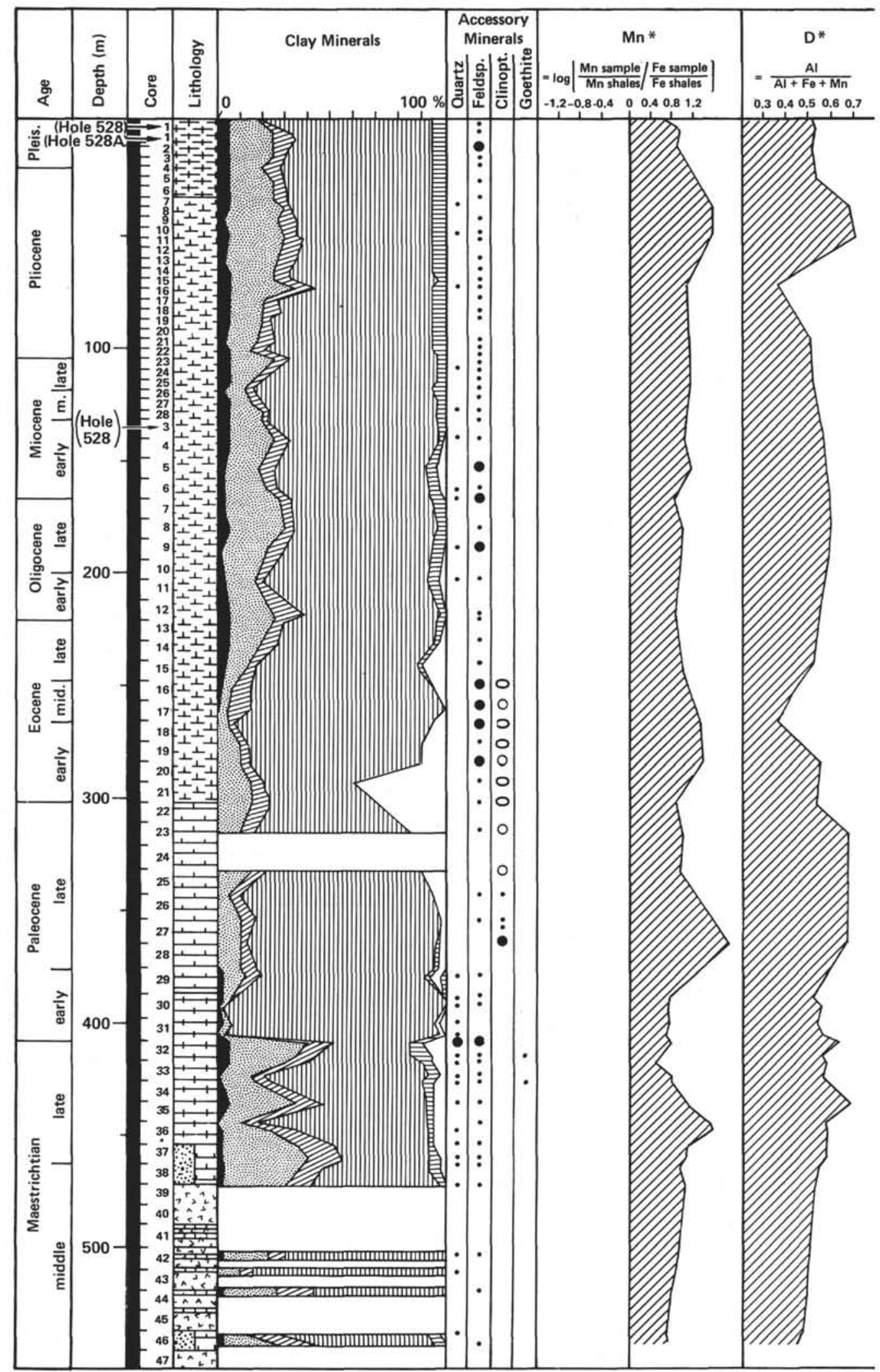

Figure 6. Site 528 results. 


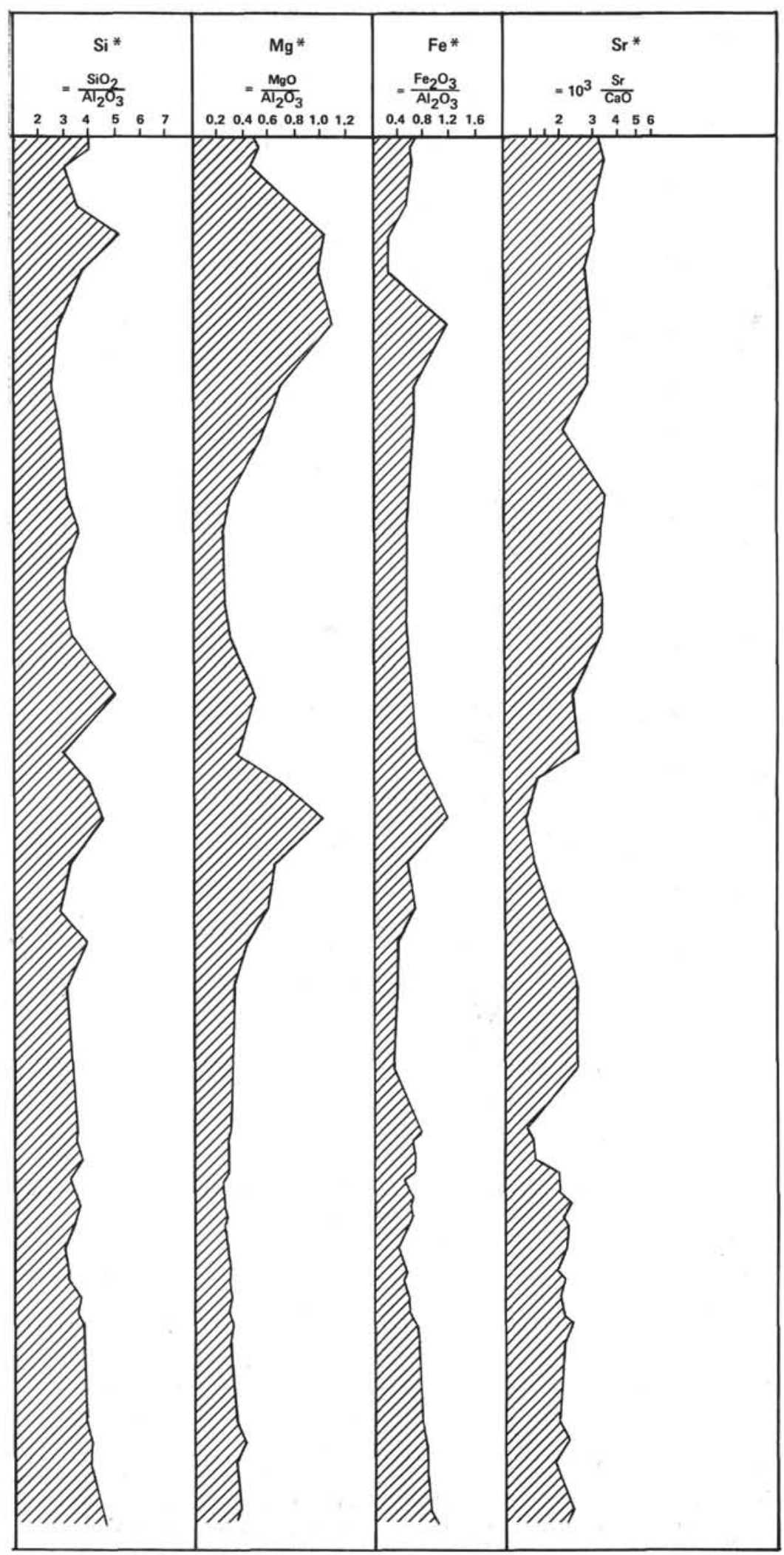

Figure 6. (Continued). 


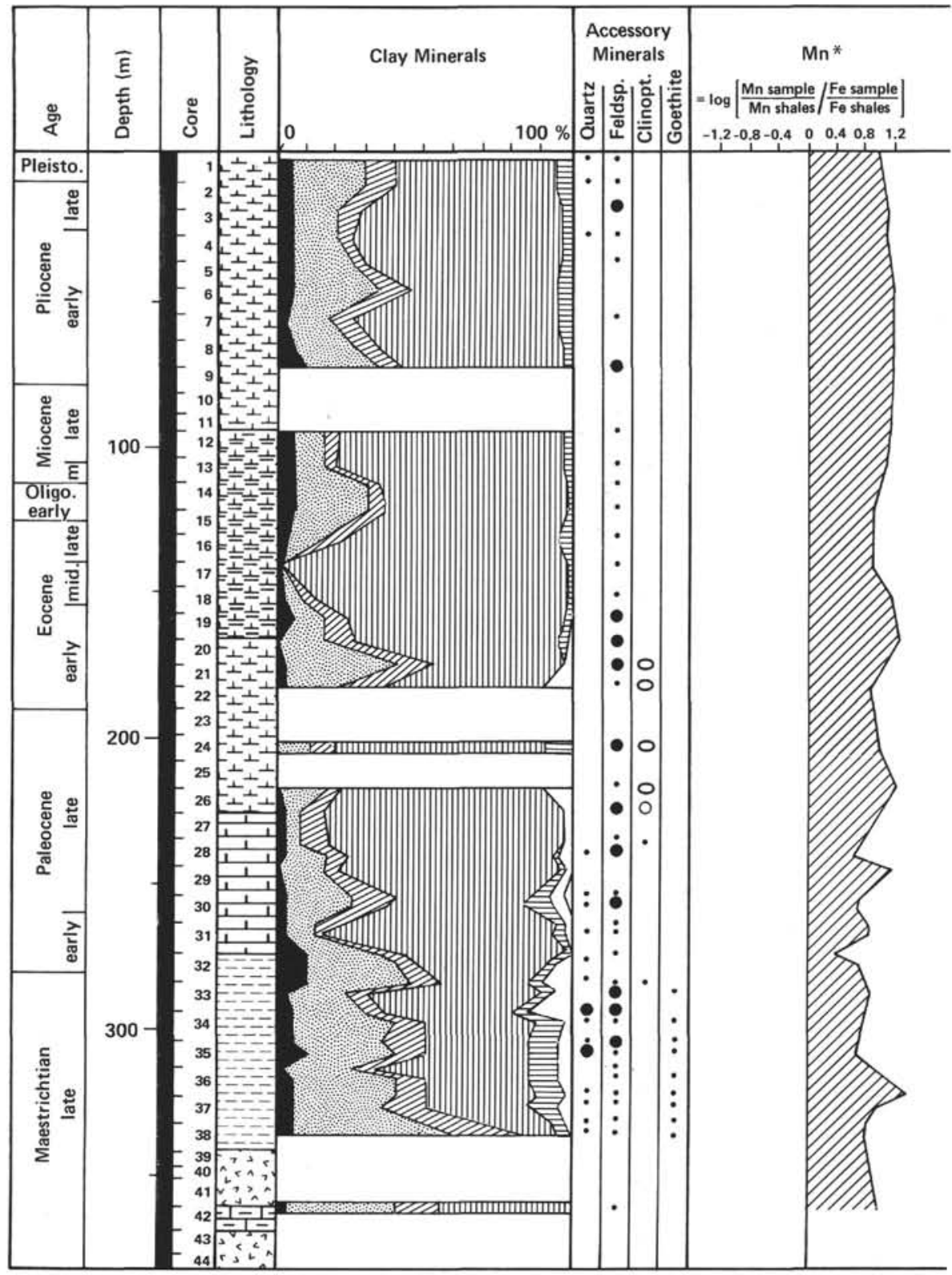

Figure 7. Site 527 results.

weathering and of confined coastal basins are recognizable in this unit.

From the upper Eocene up (Cores 16-1), the diminution of smectite $(45-70 \%)$, the disappearance of palygorskite, and the increased importance of chlorite (trace amounts-10\%), illite $(10 \%-30 \%)$, mixed-layer clays (trace amounts-10\%), and kaolinite (trace amounts$5 \%$ ) are all related to the progressive deterioration of climate.

\section{Geochemistry (Fig. 7 and Table 4)}

In upper Maestrichtian sediments, the geochemical criteria indicate the presence of an oxidized environment $\left(\mathrm{Mn}^{*}=0.89, \mathrm{D}^{*}=0.54, \mathrm{Fe}^{*}=0.58\right.$, and $\mathrm{Mg}^{*}=$ $0.23)$. $\mathrm{Mn}$ is higher than Fe. The variation of chemical indices and clay minerals is not greatly influenced by variation of the oxides (Chamley et al., this volume).
$\mathrm{Sr}^{*}$ (2.01) is typical of marine carbonates; its values increase between Section 527-37-3 and 527-35-4, suggesting an increase in the dissolution of the carbonates.

During the Cretaceous/Tertiary transition, chemical variations are almost certainly related to those of the clay minerals (Chamley et al., this volume).

From lower Paleocene to upper Paleocene, $\mathrm{Mn}^{*}(0.84)$ and $D^{*}(0.49)$ become typical of an oxidizing environment, and the influence of detrital components decreases.

$\mathrm{Si}^{*}$ (3.42) and $\mathrm{Mg}^{*}(0.29)$ reflect the mean composition of clay minerals. $\mathrm{Sr}^{*}$ decreases $(1.80)$ and marks a nondissolved carbonates fraction showing a strong effect of burial diagenesis on the carbonates. Dissolution of carbonates began only during the late Paleocene. From the top of the upper Paleocene to the lower Eocene, $\mathrm{Mn}^{*}(1.08), \mathrm{Mg}^{*}(0.66)$, and $\mathrm{Fe}^{*}(0.66)$ increase; 


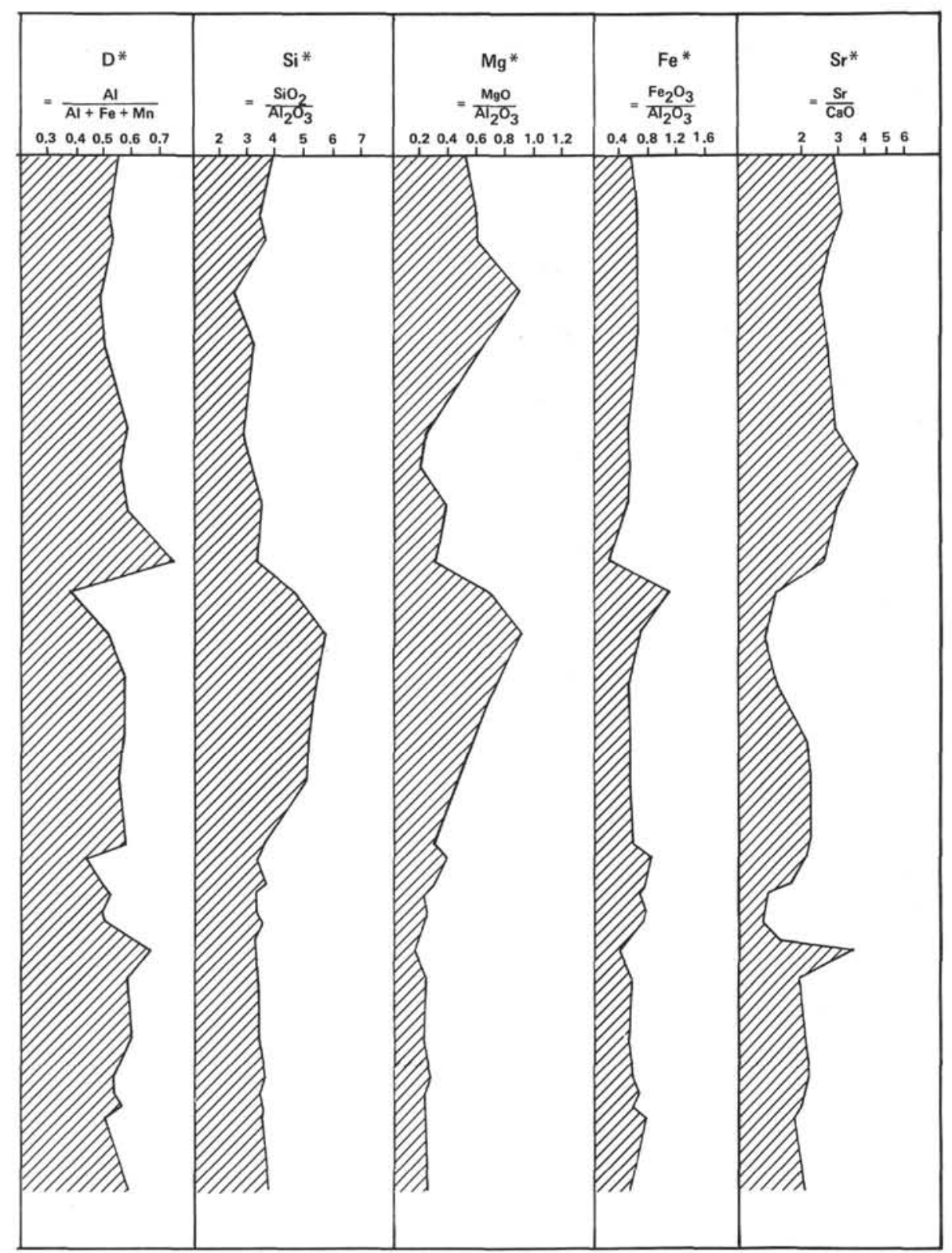

Figure 7. (Continued).

these high values are almost certainly related to volcanic events (possibly on the mid-oceanic ridge).

From middle Eocene to upper Miocene D* $(0.61)$ increases with increasing continental influence. All the chemical criteria become typical of the chemical composition of the clay minerals: $\mathrm{Si}^{*}=3.17, \mathrm{Mg}^{*}=0.29$, $\mathrm{Fe}^{*}=0.45$. $\mathrm{Sr}^{*}$ is always high (3.02) in response to a strong dissolution of the carbonate fraction. The sediments deposited between the end of the middle Eocene and the upper Eocene, as well as during the middle Miocene, are more dissolved (van Andel et al., 1977; and Le Pichon et al., 1978). During the Plio-Pleistocene, high positive $\mathrm{Mn}^{*}$ values (1.10) and slightly decreased $\mathrm{D}^{*}$ (0.51) can be explained by the presence of an oxidizing environment. $\mathrm{Si}^{*}(3.32)$ reflects only the composition of clay minerals. $\mathrm{Sr}^{*}(2.87)$ decreases slightly and only the sediments from the upper Pliocene are dissolved.

\section{TECTONICS AND SUBSIDENCE IN THE WALVIS RIDGE AREA}

In the region studied during Leg 74 , basaltic basement, dated as Campanian, was recovered at Site 525 . Volcanic emissions were produced, then altered, in a subaerial environment. As a consequence, the Campanian and Maestrichtian sediments overlying the basalt are characterized by abundant well-crystallized smectite and minor precipitation of transition elements. At Site 527, where basaltic material was produced in a submarine environment, the influence of volcanism is not recognizable in the mineralogical and geochemical data. At all sites, the sediment located above the basaltic basement contain abundant detrital clay particles; the assemblage is characterized by significant amounts of illite and mixed-layer clays principally, and geochemical indices 
Table 4. Site 527: geochemical results.

\begin{tabular}{|c|c|c|c|c|c|c|c|c|c|c|c|c|c|c|c|c|c|c|c|}
\hline $\begin{array}{l}\text { Core/Section } \\
\text { (level in } \mathrm{cm} \text { ) }\end{array}$ & $\underset{(\%)}{\mathrm{SiO}_{2}}$ & $\underset{(\%)}{\mathrm{Al}_{2} \mathrm{O}_{3}}$ & $\begin{array}{l}\mathrm{CaO} \\
(\%)\end{array}$ & $\begin{array}{c}\mathrm{MgO} \\
(\%)\end{array}$ & $\begin{array}{l}\mathrm{Na}_{2} \mathrm{O} \\
(\%)\end{array}$ & $\begin{array}{l}\mathrm{K}_{2} \mathrm{O} \\
(\%)\end{array}$ & $\begin{array}{l}\mathrm{TiO}_{2} \\
(\%)\end{array}$ & $\begin{array}{c}\mathrm{Fe}_{2} \mathrm{O}_{3} \\
(\%)\end{array}$ & $\underset{\text { (ppm) }}{\mathrm{Mn}}$ & $\underset{\text { (ppm) }}{\mathrm{Zn}}$ & $\underset{\text { (ppm) }}{\mathbf{L i}}$ & $\underset{(\mathrm{ppm})}{\mathrm{Ni}}$ & $\underset{(\mathrm{ppm})}{\mathrm{Cr}}$ & $\begin{array}{c}\mathrm{Sr} \\
\text { (ppm) }\end{array}$ & $\begin{array}{c}\mathrm{Co} \\
(\mathrm{ppm})\end{array}$ & $\underset{(\mathrm{ppm})}{\mathrm{Cu}}$ & $\begin{array}{c}\mathrm{Pb} \\
\text { (ppm) }\end{array}$ & $\underset{(\mathrm{ppm})}{\mathrm{V}}$ & $\underset{(\mathrm{ppm})}{\mathrm{Cd}}$ \\
\hline $1-2,60$ & 2.10 & 0.55 & 48.61 & 0.29 & 1.09 & 0.13 & 0.03 & 0.31 & 284 & 26 & 3 & 4 & 10 & 1,442 & 3 & 6 & 42 & 7 & 2 \\
\hline $3-1,60$ & 1.55 & 0.45 & 48.01 & 0.27 & 1.04 & 0.13 & 0.03 & 0.29 & 332 & 116 & 3 & 5 & 11 & 1,495 & 5 & 8 & 43 & 9 & 3 \\
\hline $4-1,60$ & 1.85 & 0.51 & 47.68 & 0.31 & 0.94 & 0.15 & 0.03 & 0.32 & 337 & 84 & 3 & 5 & 9 & 1,358 & 6 & 8 & 36 & 7 & 3 \\
\hline $6-1,30$ & 0.75 & 0.30 & 49.95 & 0.27 & 0.81 & 0.10 & 0.02 & 0.19 & 263 & 111 & 1 & 5 & 11 & 1,263 & 4 & 11 & 34 & 3 & 2 \\
\hline $8-2,9$ & 1.35 & 0.42 & 49.72 & 0.27 & 0.79 & 0.12 & 0.02 & 0.27 & 358 & 63 & 2 & 3 & 8 & 1,368 & 5 & 0 & 31 & 3 & 4 \\
\hline $12-1,70$ & 8.30 & 2.95 & 42.15 & 0.75 & 1.06 & 0.64 & 0.11 & 1.45 & 1,689 & 53 & 13 & 49 & 18 & 1,253 & 24 & 51 & 36 & 24 & 2 \\
\hline $13-3,60$ & 22.35 & 7.09 & 28.93 & 1.43 & 1.31 & 1.55 & 0.32 & 3.82 & 4,000 & 126 & 32 & 87 & 28 & 1,074 & 49 & 66 & 32 & 67 & 1 \\
\hline $15-1,88$ & 2.90 & 0.83 & 48.88 & 0.32 & 0.67 & 0.27 & 0.05 & 0.43 & 326 & 100 & 4 & 9 & 12 & 1,474 & 7 & 6 & 22 & 4 & 3 \\
\hline $17-2,05$ & 13.90 & 4.31 & 38.00 & 1.33 & 1.26 & 0.60 & 0.13 & 1.09 & 732 & 111 & 32 & 15 & 13 & 1,000 & 6 & 59 & 25 & 10 & 2 \\
\hline $18-3,70$ & 2.40 & 0.53 & 47.71 & 0.36 & 0.77 & 0.22 & 0.08 & 0.57 & 721 & 68 & 2 & 13 & 12 & 800 & 11 & 7 & 26 & 8 & 4 \\
\hline $20-1,52$ & 1.70 & 0.30 & 50.22 & 0.27 & 0.71 & 0.15 & 0.02 & 0.19 & 300 & 47 & 1 & 6 & 10 & 737 & 7 & 1 & 30 & 3 & 3 \\
\hline $22-1,50$ & 3.05 & 0.57 & 49.89 & 0.42 & 0.84 & 0.24 & 0.04 & 0.31 & 247 & 68 & 3 & 4 & 11 & 826 & 3 & 5 & 25 & 0 & 4 \\
\hline $24-4,16$ & 3.45 & 0.68 & 47.71 & 0.38 & 0.77 & 0.27 & 0.05 & 0.36 & 284 & 58 & 5 & 12 & 12 & 1,016 & 6 & 5 & 22 & 1 & 3 \\
\hline $26-1,102$ & 3.85 & 0.77 & 49.42 & 0.33 & 0.81 & 0.28 & 0.05 & 0.41 & 558 & 74 & 4 & 7 & 17 & 1,105 & 6 & 3 & 27 & 3 & 4 \\
\hline $28-4,80$ & 6.55 & 1.87 & 46.94 & 0.54 & 0.79 & 0.54 & 0.09 & 1.07 & 389 & 37 & 9 & 13 & 15 & 1,042 & 6 & 12 & 26 & 8 & 3 \\
\hline $29-2,8$ & 5.05 & 1.53 & 46.17 & 0.58 & 0.78 & 0.54 & 0.10 & 1.29 & 1,684 & 45 & 8 & 21 & 11 & 984 & 18 & 20 & 52 & 11 & 2 \\
\hline $30-1,99$ & 7.75 & 2.14 & 44.28 & 0.63 & 0.74 & 0.93 & 0.16 & 1.64 & 816 & 36 & 6 & 15 & 12 & 795 & 9 & 20 & 49 & 26 & 2 \\
\hline $30-3,99$ & 9.40 & 2.89 & 42.18 & 0.63 & 0.82 & 0.93 & 0.20 & 1.97 & 811 & 47 & 9 & 18 & 20 & 632 & 6 & 21 & 24 & 27 & 3 \\
\hline $31-1,88$ & 13.50 & 4.14 & 36.94 & 0.99 & 0.91 & 1.39 & 0.30 & 3.15 & 2,037 & 76 & 14 & 31 & 16 & 532 & 16 & 54 & 51 & 47 & 1 \\
\hline $31-3,97$ & 13.75 & 4.02 & 38.37 & 0.92 & 0.94 & 1.51 & 0.30 & 2.86 & 1,842 & 71 & 13 & 26 & 14 & 537 & 12 & 48 & 46 & 32 & 1 \\
\hline $32-1,26$ & 30.00 & 9.45 & 23.10 & 1.65 & 1.29 & 2.26 & 0.48 & 4.58 & 1,037 & 89 & 27 & 28 & 34 & 389 & 14 & 38 & 22 & 61 & 0 \\
\hline $32-3,26$ & 47.70 & 14.89 & 6.82 & 2.46 & 1.60 & 3.76 & 0.69 & 5.79 & 2,553 & 182 & 53 & 44 & 36 & 242 & 14 & 62 & 18 & 184 & 0 \\
\hline $33-3,131$ & 9.80 & 2.95 & 40.18 & 0.69 & 0.78 & 0.93 & 0.09 & 1.56 & 953 & 68 & 12 & 12 & 16 & 784 & 5 & 15 & 24 & 13 & 5 \\
\hline $35-4,27$ & 18.05 & 5.46 & 34.15 & 1.16 & 0.86 & 1.61 & 0.29 & 2.79 & 1,121 & 79 & 19 & 13 & 23 & 705 & 4 & 9 & 25 & 47 & 2 \\
\hline $37-1$ & 9.50 & 2.72 & 41.85 & 0.68 & 0.67 & 0.96 & 0.16 & 1.47 & 3,000 & 84 & 10 & 18 & 19 & 900 & 5 & 8 & 19 & 55 & 2 \\
\hline $37-3$ & 15.55 & 4.55 & 36.49 & 0.98 & 0.77 & 1.51 & 0.26 & 2.89 & 2,150 & 137 & 14 & 24 & 21 & 753 & 5 & 17 & 23 & 44 & 2 \\
\hline $38-1,101$ & 18.60 & 5.44 & 34.15 & 1.19 & 0.78 & 1.81 & 0.25 & 3.07 & 1,710 & 84 & 14 & 26 & 24 & 674 & 5 & 23 & 11 & 44 & 1 \\
\hline $38-4,49$ & 15.30 & 4.50 & 35.82 & 0.99 & 0.77 & 1.58 & 0.28 & 3.32 & 1,784 & 100 & 14 & 31 & 25 & 668 & 5 & 10 & 19 & 60 & 2 \\
\hline $42-1,54$ & 34.10 & 9.69 & 20.19 & 2.19 & 1.15 & 2.63 & 0.50 & 4.93 & 4,000 & 121 & 33 & 34 & 37 & 405 & 7 & 54 & 23 & 62 & 0 \\
\hline
\end{tabular}

point to the importance of detrital components. The presence of a youthful continental morphology, rejuvenated by tectonism, is suggested (Robert et al., 1979). The detrital influence was more important at Sites 527 and 528 , located in deeper water and with a more extensive alluvial source area than Sites 525 and 529 , located in a shallow-water environment. Moreover, at these sites the occurrence of volcanogenic smectite has diluted the detrital supply. Tectonism and volcanism seem to have been directly involved in the evolution of the Walvis Ridge during the Campanian and the Maestrichtian. Volcanism disappeared subsequently, and the importance of tectonism decreased from late Maestrichtian to late Paleocene.

Changes in the geochemical index $\mathrm{Sr}^{*}$ shows that dissolution effects were very weak during the Late Cretaceous and increased progressively during the Paleocene. This geochemical trend parallels the decrease in illite and mixed-layer clays in the clay fraction and may have been caused by the deepening of the sites. As observed on the Rio Grande Rise (Robert, 1981), subsidence accompanied tectonic activity on the Walvis Ridge from Campanian to Paleocene.

Fluctuations appear in the general trend of $\mathrm{Sr}^{*}$ (Fig. 8). During the late Maestrichtian, a short increase in dissolution which appeared at Site 527 is also present at the shallower Site $\mathbf{5 2 8}$, where it is relatively weak. It is absent at the other sites. During the early Paleocene, the occurrence of slumps diminished the effect of dissolution on the sediment. Later, in the late Paleocene, there is a slight dissolution effect at all the sites. Generally, it is most marked at the deepest, Site 527, and decreases toward the southeast; the slightest influence is recorded at Site 525 (the shallowest site for which geochemical data are available). This depth pattern is similar to the present one, suggesting that there has been no important

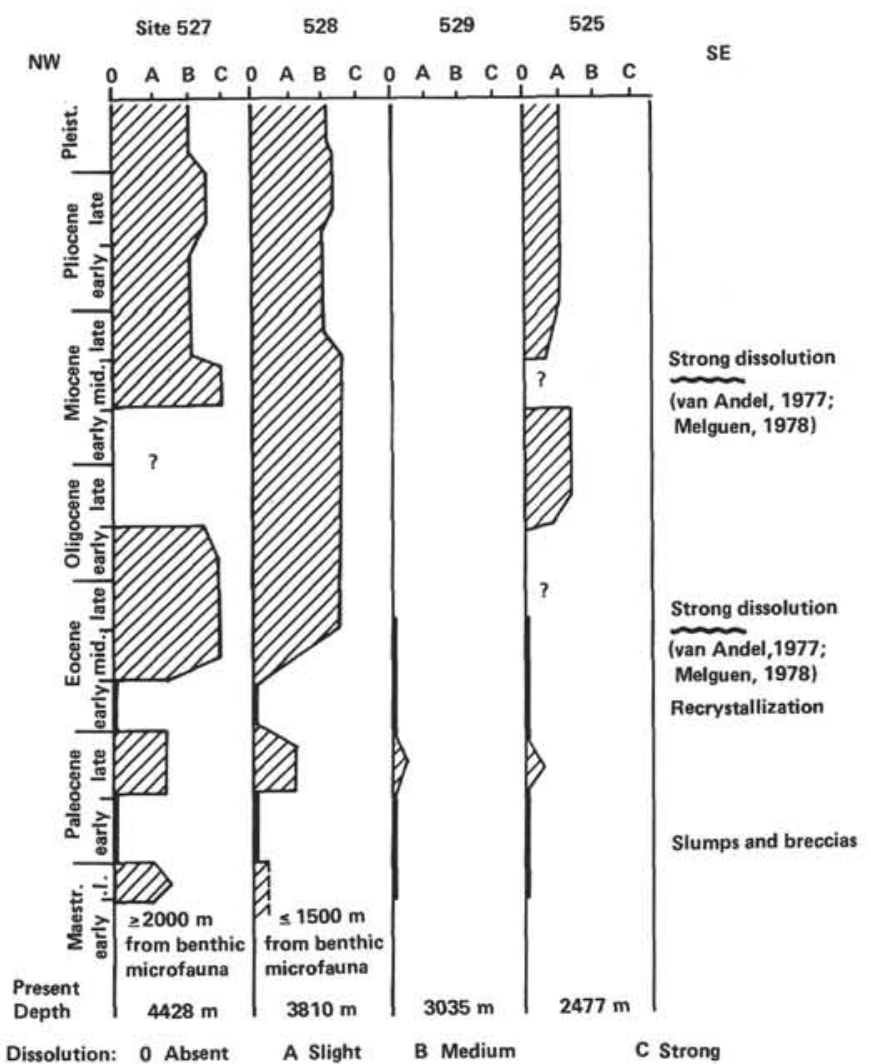

Figure 8. Dissolution of carbonates.

change in the relative depth position of the site since the late Paleocene.

From upper Paleocene to upper Eocene, the abundance of chlorite, illite, and mixed-layer clays points to a renewal of the tectonic activity on the Walvis Ridge. The paroxysm seems to have occurred at the end of the 
late Paleocene and in the early Eocene. It marks the end of the tectonic activity in this region which began during the Campanian, contemporaneously with a change in the direction and speed of ocean opening (Goslin et al., 1974).

At the same time, the deposition of abundant palygorskite in the sediment suggests an important contribution from enclosed or semi-enclosed confined basins. A local phase of subsidence could have induced submergence of flat areas on the Walvis Ridge where palygorskite developed, as was the case on the Rio Grande Rise during the same period (Robert, 1981). Palygorskite very often occurs in long, flexible fibers, indicating that it formatted close to the sites (Plate 1). Moreover, the presence of fibers growing at the periphery of wellshaped particles suggests that palygorskite probably developed by transformation processes, as shown by Trauth (1974).

During the late Eocene, palygorskite disappeared. Clay mineral assemblages are uniform at all sites where smectite dominates the clay fraction, and point to similar sources of detrital supply. The Walvis Ridge, as well as Rio Grande Rise, was probably mostly submerged by this time.

From the late Paleocene on, the subsidence of the Walvis Ridge was continual and can be seen in the geochemical indices (Fig. 8). From middle Eocene on, the depth gradient in dissolution observed in late Paleocene sediments is also present, with some differences: no dissolution occurred at Sites 525 and 529, whereas the deeper Site 528 and especially Site 527 were influenced by dissolution effects. The persistence of increased dissolution since the late Paleocene was probably related to the progressive deepening of the site toward more chemically active deep waters as the ridge subsided.

\section{CLIMATIC AND OCEANOGRAPHIC EVOLUTION OF THE WALVIS RIDGE AREA}

From the upper Eocene upward, all the sedimentary sequences recovered show an irregular increase in chlorite, illite, and mixed-layer clays. This trend is a consequence of the Cenozoic climatic cooling which began in the middle to late Eocene (Shackleton and Kennett, 1975). Climatic cooling was responsible for the progressive diminution in the intensity of weathering on the continents, which prevented the complete development of soils. As a consequence, the abundance of smectite or kaolinite decrease, whereas chlorite, illite, and mixedlayers become abundant (Chamley, 1979). A peak in the abundance of these minerals occurred in late Miocene to early Pliocene sediments, at a time when the Antarctic ice sheet developed (Shackleton and Kennett, 1975) and reached its greatest extent (Mercer, 1978).

Compared to clay mineral assemblages recovered in other regions of the South Atlantic, such as the MidAtlantic Ridge (Maillot and Robert, 1980), the Falkland Plateau (Robert and Maillot, in press) or the other sites from the Walvis Ridge, the relative abundance of clay species at Site 526 appears more homogeneous; fluctuations are present, but one cannot discern any important break, probably because the currents present on the flank of the Walvis Ridge locally removed sediments (as shown by Bornhold and Summerhayes, 1977) and homogenized the composition of the clay fraction. These currents may have been efficient since the early Oligocene, when the importance of global circulation increased and when the Benguela upwelling system started (Peypouquet, personal communication, 1981).

From the upper Eocene on, the geochemical index of dissolution ( $\left.\mathrm{Sr}^{*}\right)$ also shows a progressive and irregular increase (Fig. 8). The first stage occurred during the late Eocene, in agreement with the major phase of carbonate dissolution evidenced by investigations of the calcareous biogenic components in the southeast Atlantic (van Andel et al., 1977, Melguen, LePichon, et al., 1978). Another comparable stage occurred during the middle Miocene. During the late Miocene and early Pliocene, a smooth increase in the dissolution occurred and reached its maximum at the early/late Pliocene boundary. The main stages of carbonate dissolution recorded correspond to the phases of shoaling of the CCD observed by van Andel et al. (1977) and Melguen, LePichon, et al. (1978) and attributed to a cooling of bottom waters. The Pliocene phase of dissolution had not previously been noted and may be related to an increase in the cooling or in the circulation of bottom waters.

Cenozoic clay assemblages show also geographical differences in the abundance of chlorite, illite, and mixed layers (Fig. 9). These minerals are more abundant at Sites 525 and 526, located in a shallower environment, than at Sites 527 and 528, drilled in deeper waters where smectite dominates. The difference is noted first in the Eocene, and its importance increased with time until the Plio-Pleistocene.

These depth differences can be explained by comparison with data on suspended matter and recent sediments, taking into account the vertical distribution of the different water masses and oceanic currents (Sverdrup et al., 1942; Dietrich, 1963; Reid et al., 1977). Elevated sites, such as 525 and 526, are more subject to the Benguela, which flows from the south and southeast. This current favors the transport of detrital components from arid regions of South Africa which have been carried to the ocean by rivers and winds. In addition to smectite, the detrital supply probably contains more abundant chlorite, illite, and mixed-layers, as is the case along the arid coast of northwest Africa (Bornhold, 1973; Diester-Haass and Chamley, 1980; Robert, 1980).

Deeper sites, such as 527 and 528, which contain more abundant smectite, are subjected to intermediate and deep waters formed around Antarctica. Previous studies have shown that smectite increases in the sediments under the influence of Antarctic Bottom Water (Chamley, 1975; Melguen, Debrabant et al., 1978), and that smectite probably comes from erosional processes on Antarctica or on the seafloor of the Southern Ocean (Robert and Maillot, in press). Thus, deep and bottom waters enriched in smectite probably enter the Angola Basin through the Romanche Fracture Zone and through the Walvis Passage, located close to the area studied during Leg 74 (Connary and Ewing, 1974; Mc- 


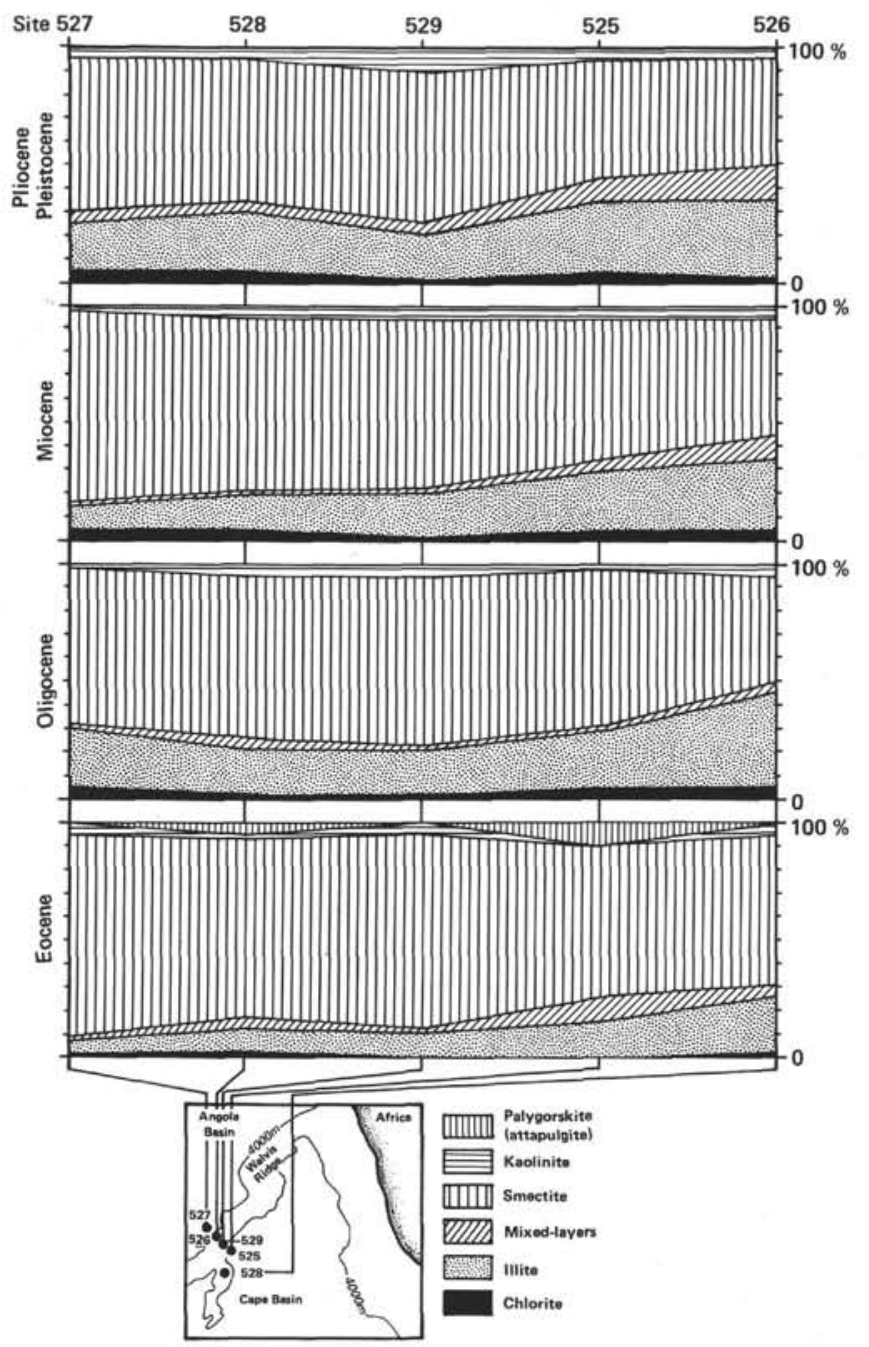

Figure 9. Cenozoic evolution of clay minerals, Walvis Ridge.

Coy and Zimmerman, 1977). These trends became apparent by late Eocene, contemporaneous with the beginning of the Cenozoic climatic cooling.

During the Late Cretaceous, variations of the geochemical index $\mathrm{Mn}^{*}$ depended on volcanic influences (Chamley et al., this volume). During Cenozoic time, the influence of metalliferous accumulations associated with volcanism or hydrothermal activity cannot be excluded. However, the coincidence of carbonate dissolution with metalliferous accumulation events (Fig. 10) leads us to interpret the $\mathrm{Mn}^{*}$ data as being greatly affected by oceanic currents (Maillot, 1980). Schematically, if one considers the paleobathymetric position of the sites, (1) an increase in $\mathrm{Mn*}$ may be related to an increased influence of oxidized surficial or bottom waters or to a decrease in the temperature of bottom waters, and (2) a decrease in $\mathrm{Mn}^{*}$ may be due to either the lack of oceanic circulation leading to the presence of euxinic environments or the increased influence of poorly oxidized intermediate water masses.

In the area under consideration, $\mathrm{Mn}^{*}$ retains positive values, the oceanic environment being always oxidized. Different results were obtained at Sites 362 (Leg 40) and

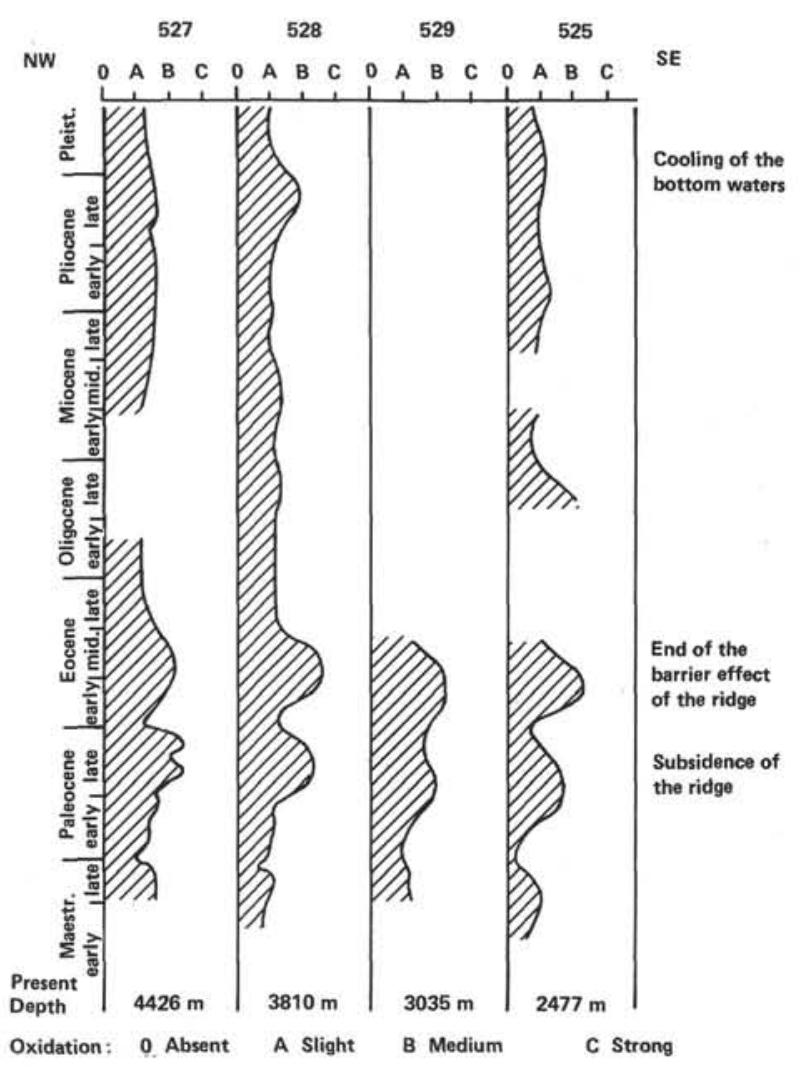

Figure 10. Oxidation of the marine paleoenvironment.

532 (Leg 75), where oxygen minimum layers were present from the middle Miocene to the Pleistocene (Maillot and Robert, 1980; Maillot and Robert, in press). Two major increases in metalliferous components occurred simultaneously at the four sites of Leg 74 , during the late Paleocene and the middle Eocene. This points to the existence of two main stages in the development of the circulation of deep water masses. These are probably related to the subsidence of the Walvis Ridge, which progressively favored the exchanges of water masses between the Angola and Cape basins, and to changes in the vertical structure of the water masses in the South Atlantic.

A brief increase in Mn* during late Pliocene time is evident, especially at Site 528 . This increase in metalliferous concentrations is probably related to an increase in the velocity or in the cooling of deep waters following the development of the Arctic ice sheet.

\section{CONCLUSION}

Combined inorganic geochemical and clay mineralogical studies on sediments recovered during Leg 74 aid in the reconstruction of both continental and oceanic paleoenvironments since the Late Cretaceous. Thus, information obtained on volcanics, tectonics, and on marine and continental influences during the Late Cretaceous enable us to determine the geologic evolution of the Walvis Ridge during the period concerned. On the other hand, inorganic geochemical and clay mineralogical data permit us to follow the changes which occurred in climate and oceanic circulation during Cenozoic time. 
The proximity of the sites permits us to examine the history of sedimentation both in its essential features and in detail.

\section{ACKNOWLEDGMENTS}

Thanks are due to the National Science Foundation for samples from Leg 74. Financial support was provided by the CNEXO (France) for geochemical studies. B. Bornhold, H. Chamley, T. Moore, and P. Borella reviewed and improved the original manuscript, we also thank M. Acquaviva and C. H. Froget for technical assistance in clay minerals analysis, E. Hanton and C. Maillot for assistance in geochemical analysis, M. Bocquet for the illustrations, J. Carpentier for the photographs, and F. Dujardin for typing the manuscript.

\section{REFERENCES}

Bausch, W. M., 1968. Recent developments in carbonate sedimentology in Central Europe. In Müller, G., and Friedman, G. M. (Eds.), Outlines of the Distribution of Strontium in Marine Limestones: Berlin (Springer Verlag), pp. 106-115.

Bornhold, B. D., 1973. Late Quaternary sedimentation in the Eastern Angola Basin. WHOI Technical Report, No. 73-80.

Bornhold, B. D., and Summerhayes, C., 1977. Scour and deposition at the foot of the Walvis Ridge, in the northernmost Cape Basin, South Atlantic. Deep Sea Res., 24:743-752.

Boström, K., 1970. Submarine volcanism as a source of iron. Earth Planet. Sci. Lett., 9:348-384.

Boström, K., Joensuu, O., Valdes, S., Charm, W., and Glacum, R., 1976. Geochemistry and origin of East Pacific sediments sampled during DSDP Leg 34. In Yeats, R. S., Hart, S. R., et al., Init. Repts. DSDP, 34: Washington (U.S. Govt. Printing Office), 559-574.

Boström, K., Joensuu, O., Valdes, S., and Riera, M., 1972. Geochemical history of South Atlantic ocean sediments since Late Cretaceous. Mar. Geol., 12:85-121.

Boström, K., and Peterson, M. N., 1969. The origin of the aluminum poor ferromanganoan sediments in areas of high heat flow in the East Pacific Rise. Mar. Geol., 7:427-447.

Chamley, H., 1975. Influence des courants profonds au large du Brésil sur la sédimentation argileuse récente. géme Congr. Intern. Sédimentologie (Nice), 8:13-21.

1979. North Atlantic clay sedimentation and paleoenvironment since the late Jurassic. In Talwani, M., Hay, W., and Ryan, W. B. F. (Eds.), Deep Drilling Results in the Atlantic Ocean. Continental Margins and Paleoenvironment: Washington (Am. Geophys. Union), pp. 342-360.

Chamley, H., and Robert, C., 1979. Late Cretaceous to early Paleocene environmental evolution expressed by the Atlantic clay sedimentation. In Christensen, W. K., and Birkelund, T. (Eds.), Cretaceous-Tertiary Boundary Events Symposium (Vol. 2): Copenhagen (University of Copenhagen), 71-77.

, in press. Paleoenvironmental significance of clay deposits in Atlantic black shales. Cretaceous Res.

Connary, S. D., and Ewing, M., 1974. Penetration of Antarctic Bottom Water from the Cape Basin into the Angola Basin. J. Geophys. Res., 79(3):463-469.

Diester-Haass, L., and Chamley, H., 1980. Oligocene climatic, tectonic, and eustatic history off NW Africa (DSDP Leg 41, Site 369). Oceanol. Acta, 3:115-126.

Dietrich, G., 1963. General Oceanography, An Introduction: New York (Wiley Interscience).

Dunoyer de Segonzac, G., 1969. Les Minéraux argileux dans la Diagenèse. Passage au Métamorphisme. Sci. géol. (Strasbourg), Mem. 29.

Elderfield, H., 1977. The form of manganese and iron in marine sediments. In Glasby, G. P. (Ed.), Marine Manganese Deposits: Amsterdam (Elsevier), pp. 269-290.

Frakes, L. A., 1979. Climates throughout Geologic Time: Amsterdam (Elsevier).

Goldberg, E. D., and Griffin, J. J., 1964. Sedimentation rates and mineralogy in the South Atlantic. J. Geophys. Res., 69: 4293-4309.
Goslin, J., Mascle, J., Sibuet, J.-C., and Hosking, H., 1974. Geophysical study of the Easternmost Walvis Ridge, South Atlantic: Morphology and shallow structure. Geol. Soc. Am. Bull., 85: 619-632.

Krishnaswami, S., 1976. Authigenic transition elements in Pacific pelagic clays. Geochim. Cosmochim. Acta, 40:425-434.

LePichon, X., Melguen, M., and Sibuet, J.-C., 1978. A schematic model of the evolution of the South Atlantic. Advances in Oceanography: London/Charnock and Deacon., pp. 1-48.

McCoy, F. W., and Zimmerman, H. B., 1977. A history of sediment lithofacies in the South Atlantic Ocean. In Supko, P. R., PerchNielsen, K., et al., Init. Repts. DSDP, 39: Washington (U.S. Govt. Printing Office), 1047-1080.

Maillot, H., 1980. Géochimie des sédiments crétacés et cénozoiques de la marge atlantique Sud-orientale (Leg 40 DSDP). Rev. Géol. dyn. Géogr. Phys., 22:75-83.

Maillot, H., and Robert, C., 1980. Minéralogie et géochimie des sédiments crétacés et cenozoïques de l'Océan Atlantique Sud (marge africaine, dorsale médio-atlantique). Bull. Soc. Géol. France, 22:777-788.

Maillot, H., and Robert, C., in press. Paleoenvironmental significance of clay mineralogical and inorganic geochemical data, Angola Basin and Walvis Ridge (DSDP Leg 75), in press. In Hay W. W., Sibuet, J.-C., et al., Init. Repts. DSDP, 75: Washington (U.S. Govt. Printing Office).

Maxwell, A. E., Von Herzen, R. P., et al., 1970. Init. Repts. DSDP, 3: Washington (U.S. Govt. Printing Office).

Melguen, M., 1978. Facies evolution, carbonate dissolution cycles in sediments from the eastern South Atlantic (DSDP Leg 40) since the Early Cretaceous. In Bolli, H. M., Ryan, W. B. F., et al., Init. Repts. DSDP, 40: Washington (U.S. Govt. Printing Office), 981-1024.

Melguen, M., Debrabant, P., Chamley, H., Maillot, H., Hoffert, M., and Courtois, C., 1978. Influence des courants profonds sur les faciès sédimentaires du Vema Channel (Atlantique Sud) à la fin du Cénozoïque. Bull. Soc. géol. France, 20:121-136.

Melguen, M., LePichon, X., and Sibuet, J.-C., 1978. Paleoenvironment de l'Atlantique Sud. Bull. Soc. geol. France, 20:471-489.

Mercer, J. H., 1978. Glacial development and temperature trends in the Antarctic and in South America. In Van Zinderen Bakker, E. M., and Balkema A. A. (Eds.), Antarctic Glacial History and World Paleoenvironments: Rotterdam (A. A. Balkema), pp. 73-93.

Millot, G., 1964. Géologie des argiles: Paris (Masson).

Nekrassov, B., 1966. Chimie minerale: Generalites et Etude des Elements: Paris (Editions de Moscou).

Paquet, H., 1969. Evolution géochimique des Minéraux argileux dans les Altérations et les Sols des Climats méditerranéens et tropicaux à Saisons constratées. Sci. géol. (Strasbourg), Mem. 30.

Pedro, G., 1968. Distribution des principaux types d'altération chimique à la surface du globe. Présentation d'une esquisse géographique. Rev. Géogr. phys. Géol. dyn., 10:457-470.

Reid, J. L., Nowlin, W. D., and Patzert, W. C., 1977. On the characteristics and circulation of the Southwestern Atlantic Ocean. $J$. Phys. Oceanogr., 7:62-91.

Robert, C., 1980. Climats et courants cénozoïques dans l'Atlantique Sud d'après l'étude des minéraux argileux (Legs 3, 39 et 40 DSDP). Oceanog. Acta, 3:369-376.

1981. Santonian to Eocene palaeogeographic evolution of the Rio Grande Rise (South Atlantic) deduced from clay mineralogical data (DSDP Legs 3 and 39). Paleogeogr., Paleoclimatol., Paleoecol., 33:311-326.

Robert, C., Herbin, J. P., Deroo, G., Giroud d'Argoud, G., and Chamley, H., 1979. L'Atlantique Sud au Crétacé d'après l'étude des minéraux argileux et de la matière organique (Legs 39 et 40 DSDP). Oceanog. Acta, 2:209-218.

Robert, C., and Maillot, H., in press. Paleoenvironmental significance of clay mineralogical and geochemical data, Southwest Atlantic (DSDP Legs 36 and 71). In Ludwig, W., Krashenninikov, V. A., et al., Init. Repts. DSDP, 71: Washington (U.S. Govt. Printing Office).

Shackleton, N., and Kennett, J. P., 1975. Paleotemperature history of the Cenozoic and the initiation of Antarctic glaciation: Oxygen 
and carbon isotope analysis in DSDP Sites 277, 279 and 281. In Kennett, J. P., Houtz, R. E., et al., Init. Repts. DSDP, 29: Washington (U.S. Govt. Printing Office), 743-756.

Sverdrup, H. U., Johnson, M. W., and Fleming, R. H., 1942. The Oceans: Their Physics, Chemistry, and General Biology: Englewood Cliffs (Prentice Hall Inc.).

Trauth, N., 1974. Argiles évaporitiques dans la sédimentation carbonatée continentale tertiaire. Bassins de Paris, de Mormoiron et de Salinelles (France), Jbel Ghassoul (Maroc): Strasbourg.
Turekian, K. K., 1965. Some aspects of the geochemistry of marine sediments. In Reily, J. P., and Skirrow, G. (Eds.), Chemical Oceanography: London (Academic Press), 2:81-126.

van Andel, T. H., Thiede, J., Sclater, J. G., and Hay, W. W., 1977. Depositional history of the South Atlantic ocean during the last 125 million years. J. Geol., 85:651-698. 


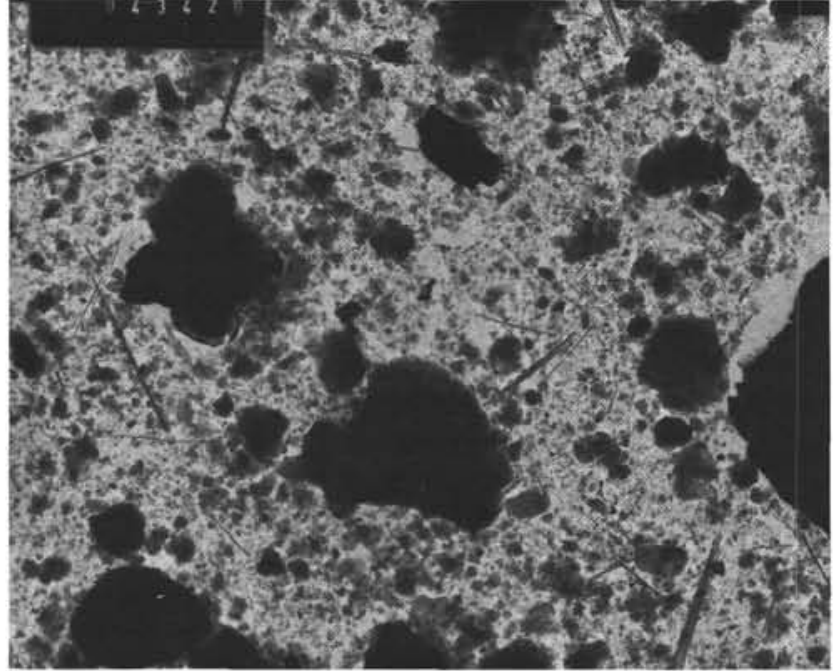

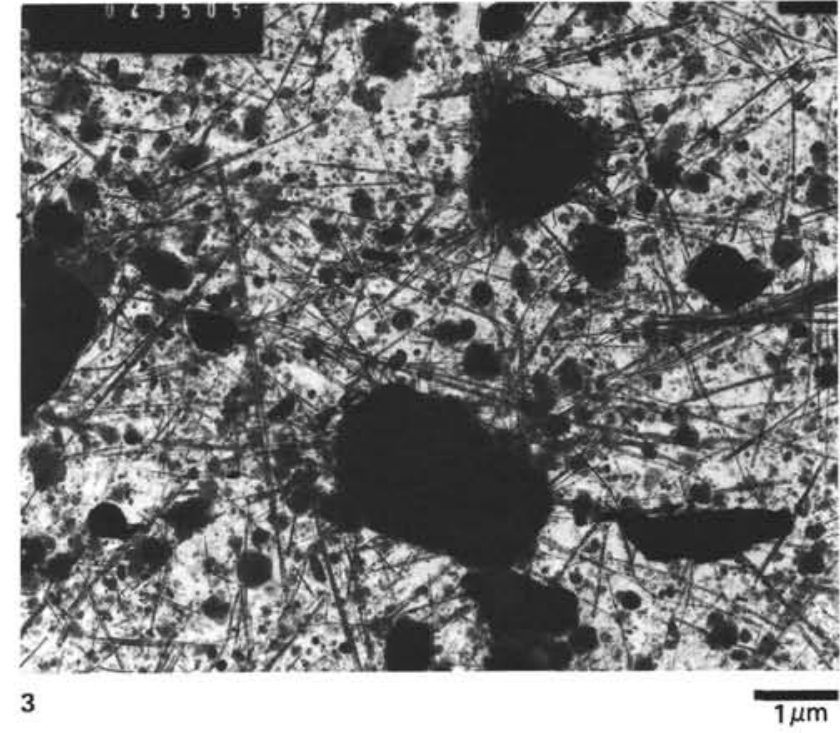

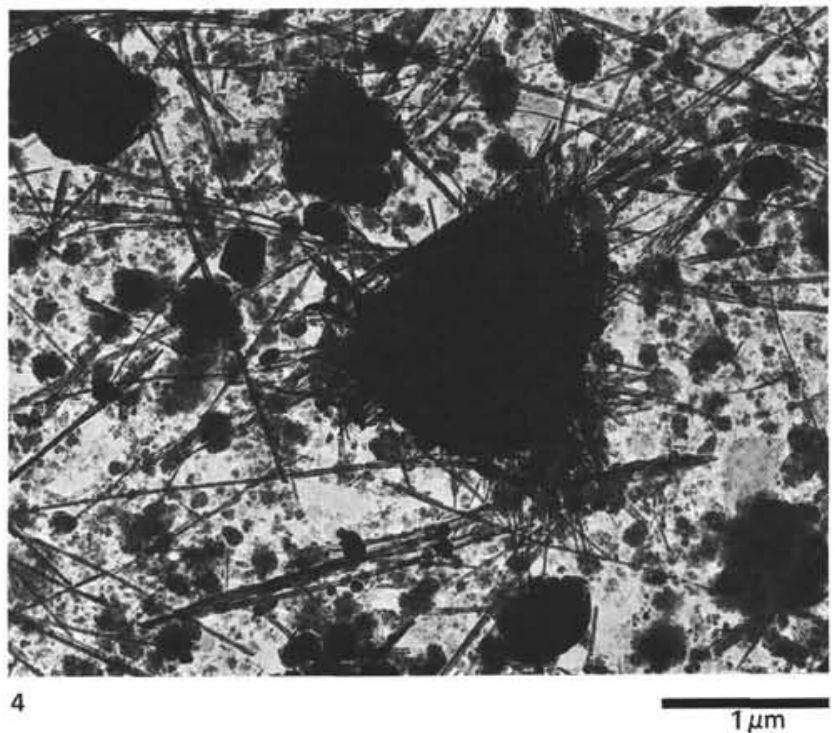

Plate 1. Electromicrographs (scale bar $=1 \mu \mathrm{m}) \quad$ 1. Sample 526A-17-2, $70 \mathrm{~cm}(\times 12,500)$; middle Miocene palygorskite in short, straight fibers; smectite in fleecy particles; well-shaped illite. 2. Sample $527-24-4,16 \mathrm{~cm}(\times 8000)$; late Paleocene; palygorskite fibers; well-shaped illite; smectite with blurred contours. 3. Sample 528-21-1, $96 \mathrm{~cm}(\times 10,000)$; early Eocene; palygorskite in long, straight, or flexuous fibers; smectite with blurred contours; well-shaped illite. 4. Detail of Fig. $3(\times 20,000)$; early Eocene; fibers of palygorskite, probably growing at the periphery of a dense particle (illite?) 